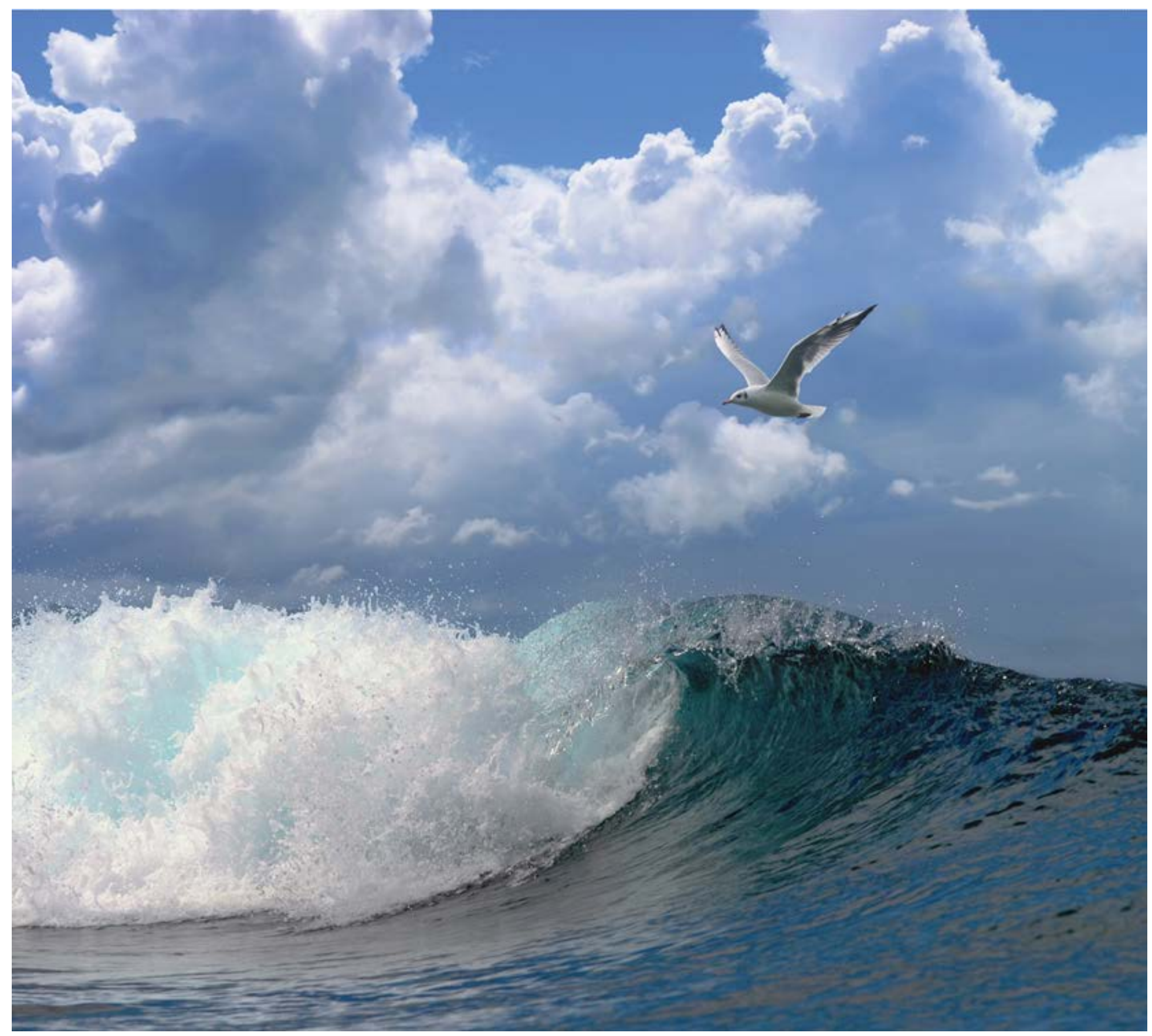

\title{
Vergelijkend vissen: dag- nacht en boomkor-stortkuil in het Volkerak
}




\section{Vergelijkend vissen: dag-nacht en boomkor-stortkuil in het Volkerak}

Auteur(s): $\quad$ Karen van de Wolfshaar, Chun Chen en Ben Griffioen

Publicatiedatum: 31 mei 2017

Wageningen Marine Research IJ muiden, mei 2017

Wageningen Marine Research rapport C048/17 
Karen van de Wolfshaar, Chun Chen, Ben Griffioen, 2017 Vergelijkend vissen: dag-nacht en boomkorstortkuil in het Volkerak. Wageningen Marine Research Wageningen UR (University \& Research centre), Wageningen Marine Research rapport C048/17, 43 blz.

Keywords: Volkerak, stortkuil, boomkor, MWTL bemonstering.

Opdrachtgever: RWS

T.a.v.: Eddy Lammmens

Zuiderwagenplein 2

8224 AD Lelystad

Wageningen Marine Research Wageningen UR is ISO 9001:2008 gecertificeerd.

Dit rapport is gratis te downloaden van https://doi.org/ 10.18174/416453

Wageningen Marine Research verstrekt geen gedrukte exemplaren van rapporten.

(c) 2016 Wageningen Marine Research Wageningen UR

Wageningen Marine Research, onderdeel van Stichting Wageningen Research KvK nr. 09098104,

IMARES BTW nr. NL 8113.83.696.B16. Code BIC/SWIFT address: RABONL2U IBAN code: NL 73 RABO 0373599285
De Directie van Wageningen Marine Research is niet aansprakelijk voor gevolgschade, noch voor schade welke voortvloeit uit toepassingen van de resultaten van werkzaamheden of andere gegevens verkregen van Wageningen Marine Research opdrachtgever vrijwaart Wageningen Marine Research van aanspraken van derden in verband met deze toepassing.

Dit rapport is vervaardigd op verzoek van de opdrachtgever hierboven aangegeven en is zijn eigendom. Niets uit dit rapport mag weergegeven en/of gepubliceerd worden, gefotokopieerd of op enige andere manier gebruikt worden zonder schriftelijke toestemming van de opdrachtgever. 


\section{Inhoud}

$\begin{array}{lr}\text { Samenvatting } & 4\end{array}$

$\begin{array}{llr}1 & \text { Inleiding } & 5\end{array}$

2 Bemonstering $\quad 6$

3 Resultaten $\quad 9$

3.1 Aantal soorten $\quad 9$

$\begin{array}{ll}3.2 & \text { Lengte frequentie } \\ 3.3 & 10\end{array}$

$\begin{array}{lll}3.3 & \text { CPUE (Catch per unit effort) } & 13\end{array}$

$\begin{array}{llr}\text { EKR scores } & 15\end{array}$

5 Discussie $r \begin{aligned} & 17\end{aligned}$

$\begin{array}{lll}5.1 & \text { Bemonstering en analyse } & 17\end{array}$

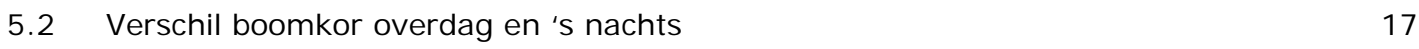

$\begin{array}{lll}5.3 & \text { Verschil stortkuil en boomkor } & 17\end{array}$

$\begin{array}{lll}5.4 & \text { Aanpassen van de bemonsteringsmethodiek } & 17\end{array}$

6 Conclusies $r \begin{aligned} & 19\end{aligned}$

$\begin{array}{llr}7 & \text { Kwaliteitsborging } & 20\end{array}$

$\begin{array}{lr}\text { Literatuur } & \mathbf{2 1}\end{array}$

$\begin{array}{lr}\text { Verantwoording } & 22\end{array}$

$\begin{array}{lr}\text { Bijlage 1: a priori power analyse } & 23\end{array}$

$\begin{array}{lr}\text { Bijlage 2: Lengte vergelijking per soort } & 24\end{array}$

Bijlage 3: Cumulatieve vergelijking op lengte, per soort 31

$\begin{array}{ll}\text { Bijlage 4: CPUE vergelijking per soort } & 38\end{array}$ 


\section{Samenvatting}

Om te toetsen of het huidige vistuig (boomkor), die gebruikt wordt in de MWTL bemonstering in het Volkerak, een stabiele vangstefficiëntie heeft, en om deze vangstefficiëntie te vergelijken met een ander frequent gebruikt tuig, is in november 2016 vergelijkend gevist. Om het effect van de helderheid op de reguliere boomkorvangsten in het Volkerak te bepalen is aan Wageningen Marine research (WMR) gevraagd naast de reguliere bemonstering overdag ook een bemonstering 's nachts uit te voeren op een vrijwel identieke manier. Daarnaast is gevraagd om 's nachts ook met een stortkuil te vissen om de efficiëntie van de boomkor in beeld te brengen. De nachttrekken en de stortkuilbemonstering vonden zo veel mogelijk op de zelfde locaties plaats als de locaties van de dagbemonstering met de boomkor. Er is vergeleken op basis van het aantal soorten, het aantal kg/ha en de lengte frequentie verdeling. Dit is gedaan voor alle soorten samen en voor de meest voorkomende soorten apart. De resultaten van de bemonstering in termen van antwoorden op de drie kernvragen staan hier beknopt weergegeven:

1. Wat is het verschil in vangst van de boomkor in termen van hoeveelheden, lengte samenstelling en aantal soorten vis tussen de dag- en nachtbemonstering?

Voor alle vis samen is er geen verschil in CPUE $(\mathrm{kg} / \mathrm{ha})$ gevonden. Alleen voor brasem en snoekbaars is de CPUE hoger 's nachts dan overdag. Er is geen verschil in het aantal soorten gevonden. Er is geen verschil in lengte frequentie verdeling voor alle soorten samen. $\mathrm{Er}$ is wel een verschil in lengte frequentie verdeling voor blankvoorn, pos en brasem.

2. Wat is het verschil in vangst in termen van hoeveelheden, lengte samenstelling en aantal soorten vis tussen de boomkor en de stortkuil (alleen nachttrekken)?

Voor alle vis samen en voor individuele soorten is er geen verschil in CPUE ( $\mathrm{kg} / \mathrm{ha})$ gevonden. De stortkuil vangt meer soorten dan de boomkor. $\mathrm{Er}$ is een verschil in lengte frequentie verdeling tussen stortkuil en boomkor (nacht) op basis van alle soorten samen. Dit geldt ook voor baars, blankvoorn, pos, zwartbekgrondel, spiering en snoekbaars.

3. Wat is het effect van tuig en tijdstip op de EKR score van het waterlichaam?

De deelmaatlatten 'aandeel brasem', 'BA+BV in \% van alle eurytopen' en 'aandeel plantminnende vis' scoren hoger voor de boomkor overdag dan 's nachts. De eindscore is hoger voor de boomkor overdag dan 's nachts. De deelmaatlatten 'aandeel brasem', 'BA+BV in \% van alle eurytopen' en 'aandeel plantminnende vis' scoren vergelijkbaar voor stortkuil en boomkor ('s nachts), en de eindscore voor de stortkuil is slechts 0.03 hoger.

Bij het mogelijk aanpassen van de bemonstering dienen het doel van de bemonstering en de praktische haalbaarheid hand in hand te gaan. Het vangen van meer vis per se levert geen ander beeld op van de populatie opbouw en daarmee geen verandering in EKR score. Het vangen van een andere lengte opbouw levert wel een ander beeld van de populatie opbouw en daarmee wel een verandering in de EKR score en kan daarom een reden zijn de bemonstering te willen wijzigen. Deze studie laat zien dat brasem en daarmee de EKR score gevoelig is voor het tijdstip van bemonsteren, 's nachts vissen met de boomkor leidt tot een lagere EKR score dan overdag vissen met de boomkor. De vangst van snoekbaars is daarentegen meer afhankelijk van het gebruikte tuig en niet zozeer van het tijdstip van bemonsteren. Kiezen voor een tuig of tijdstip is daarmee bewust kiezen voor het anders bemonsteren van soorten. Indien het wenselijk is de reeds bestaande meerjarige monitoringsreeks in het Volkerak ook in de toekomst te gebruiken, zal de invloed van een eventuele wijziging van bemonsteringsmethodiek van tevoren moeten worden gekwantificeerd. Gebeurt dit niet dan is er sprake van een trendbreuk en zullen de tot nu toe verzamelde data minder waardevol worden. 


\section{$1 \quad$ Inleiding}

In de Nederlandse zoete Rijkswateren vindt reguliere monitoring plaats van de visstand in het kader van de Monitoring Waterstaatkundige Toestand des Lands (MWTL). Deze gegevens worden gebruikt als input voor maatlat berekeningen van de Ecologische Kwaliteits Ratio's (EKR). Mede hierom is het van belang dat de monitoring een goede weerspiegeling is van de visstand en dat de vangbaarheid van vis en de efficiëntie van het gebruikte tuig niet worden beïnvloed door veranderingen in de omgeving, zoals het doorzicht.

Om te toetsen of het huidige vistuig (boomkor) een stabiele vangstefficiëntie heeft, en om deze vangstefficiëntie te vergelijken met een ander frequent gebruikt tuig, is in november 2016 vergelijkend gevist. Om het effect van de helderheid op de reguliere boomkorvangsten in het Volkerak te bepalen is aan Wageningen Marine research (WMR) gevraagd naast de reguliere bemonstering overdag ook een bemonstering 's nachts uit te voeren op een vrijwel identieke manier. Daarnaast is gevraagd om 's nachts ook met een stortkuil te vissen om de efficiëntie van de boomkor in beeld te brengen. De nachttrekken en de stortkuilbemonstering vond zo veel mogelijk op de zelfde locaties plaats als de locaties van de dagbemonstering met de boomkor.

De bemonstering is uitgevoerd door ATKB en de bemanning van de Luctor, waarbij de stortkuiltrekken in samenwerking zijn gedaan met een beroepsvisser.

De gegevens zijn geanalyseerd door WMR en worden in de volgende hoofdstukken beknopt beschreven. De analyse bestaat uit een vergelijking van de drie typen bemonstering op basis van de vangst per inspanning (cpue, biomassa/ha), lengte verdeling van verschillende vissoorten en aantal soorten. Daarnaast is voor de drie behandelingen de EKR score berekend met QBWat.

De achterliggende gedachte van vraag bij de opdrachtgever is dat de visvangsten in de MWTL bemonsteringen in de zoete Rijkswateren de laatste jaren afgenomen zijn. De vraag is of dit een afspiegeling is van de verandering van de visstand of dat het komt doordat het doorzicht in het algemeen is toegenomen. De huidige bemonstering van de Rijkswateren wordt overdag met de boomkor uitgevoerd. Doordat er 's nachts geen effect wordt verwacht van doorzicht, zou het kunnen dat de vangbaarheid van de boomkor verschilt tussen dag en nacht.

De volgende kennisvragen vormen het uitgangspunt van dit rapport:

1. Wat is het verschil in vangst van de boomkor in termen van hoeveelheden, lengte samenstelling en aantal soorten vis tussen de dag- en nachtbemonstering?

2. Wat is het verschil in vangst in termen van hoeveelheden, lengte samenstelling en aantal soorten vis tussen de boomkor en de stortkuil (alleen nachttrekken)?

3. Wat is het effect van tuig en tijdstip op de EKR score van het waterlichaam? 


\section{$2 \quad$ Bemonstering}

De bemonstering van het Volkerak heeft plaatsgevonden van 21 tot en met 23 november 2016. De boomkortrekken zijn zonder problemen verlopen. De weersomstandigheden waren ongunstig met veel wind, maar gezien de omvang van de Luctor hebben ze geen hinder ondervonden van deze weersomstandigheden. Gezien de beschikbare tijd op de Luctor (2-3 uur per avond) zijn de trekken in de nacht uitgevoerd gedurende drie avonden (maandag-, dinsdag- en woensdagavond). Vanwege de slechte weersomstandigheden bleek het niet mogelijk om de stortkuilbemonstering, welke met kleine bootjes wordt uitgevoerd, ook op maandag te starten en is AKTB met de stortkuilbemonstering begonnen op dinsdagavond. Er is geprobeerd om gelijktijdig met de Luctor op te vissen, maar vanwege de verschillen in vaarsnelheid en bleek dit maar beperkt mogelijk waardoor veel monsters met de stortkuil op een later tijdstip zijn genomen dan de monsters van de Luctor (Figuur 2).

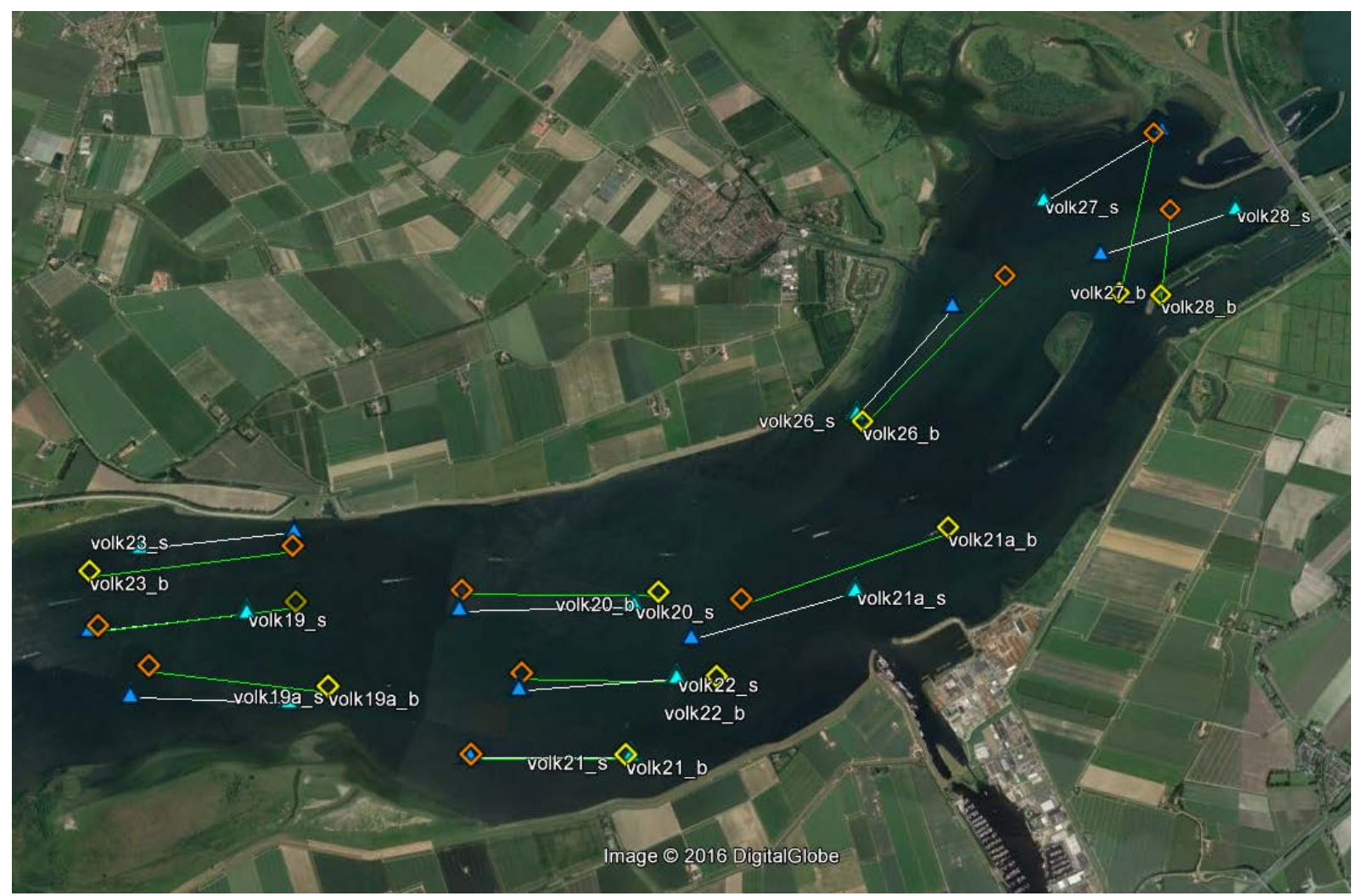

Figuur 1. GPS posities en trekken van de boomkor (groene lijnen en ruiten (start: geel; eind: oranje), "_b"; wegens grote overlap van de coördinaten dag en nacht zijn alleen de coördinaten van de dagtrekken weergegeven) en de stortkuil (witte lijnen en driehoeken (start: lichtblauw; eind: donkerblauw), “_s") in het Volkerak. De trek is niet noodzakelijkerwijs in een rechte lijn uitgevoerd.

Ook op dinsdagavond en woensdagavond was de windsterkte nog fors, waardoor ATKB op aanzienlijke afstand van de Luctor moest varen (Figuur 1). Er is daarom besloten om de trekken afzonderlijk uit te voeren op basis van de coördinaten en vaarlijnen. De trajecten zijn daarbij altijd eerst door de Luctor bevist (Figuur 2). Op dinsdagavond heeft ATKB de locaties die op maandag en dinsdag met de boomkor zijn gedaan met de stortkuil bevist.

Vanwege een stremming in de Volkeraksluizen op woensdag 23-11-2016 is al het scheepvaartverkeer door de plezierjacht sluis geleid. Hierdoor was er veel scheepvaartverkeer ter hoogte van de trekken 'volk27' en 'volk28' (Figuur 1). Door de toegenomen scheepvaartdrukte was het niet mogelijk om op de beoogde trajecten met de stortkuil (in span) te vissen. Met de boomkor was dat geen probleem omdat die goed kan manoeuvreren, maar dit gold niet voor de stortkuil. Er is besloten om de stortkuiltrekken zo dicht mogelijk tegen de oorspronkelijke boomkor trekken uit te voeren. Trek 'volk27' is een andere richting opgevist en trek 'volk28' is meer naar de sluis toe verlegd. De trekken zijn wel in de analyse meegenomen om de voorspellingskracht te vergroten. 
Figuur 2. Tijdstip per trek voor de verschillende locaties voor BK D (boomkor dag), BK N (boomkor nacht) ST N (stortkuil nacht) en het tijdstip van zonsondergang.

Er is getracht de boomkor en stortkuil trekken zoveel mogelijk overeenkomstig uit te voeren. Echter, trek 'volk23' is een meetpunt waarbij er een zeer groot diepteverschil was tussen het zetten en halen van de stortkuil (Figuur 3). De stortkuil kon niet op de diepte van de boomkortrek uitgegooid worden, waardoor besloten is de stortkuil op het talud uit te zetten en de diepte in te trekken. Er is getracht de hele afstand wel in het diepe te vissen. De vissen uit de boomkortrekken zijn gemeten conform het bestaande bemonsteringsprotocol met kleinere soorten op de $\mathrm{mm}$ (Sluis et al., 2016). Voor de stortkuil bemonstering is hiervan afgeweken en is alle vis 'to the $\mathrm{cm}$ below' $(10,0-10,99 \mathrm{~cm}-->10$ $\mathrm{cm}$ ) gemeten op initiatief van ATKB. De verschillen tussen de tuigen en de bemonstering van boomkor en stortkuil zijn weergegeven in tabel 1.

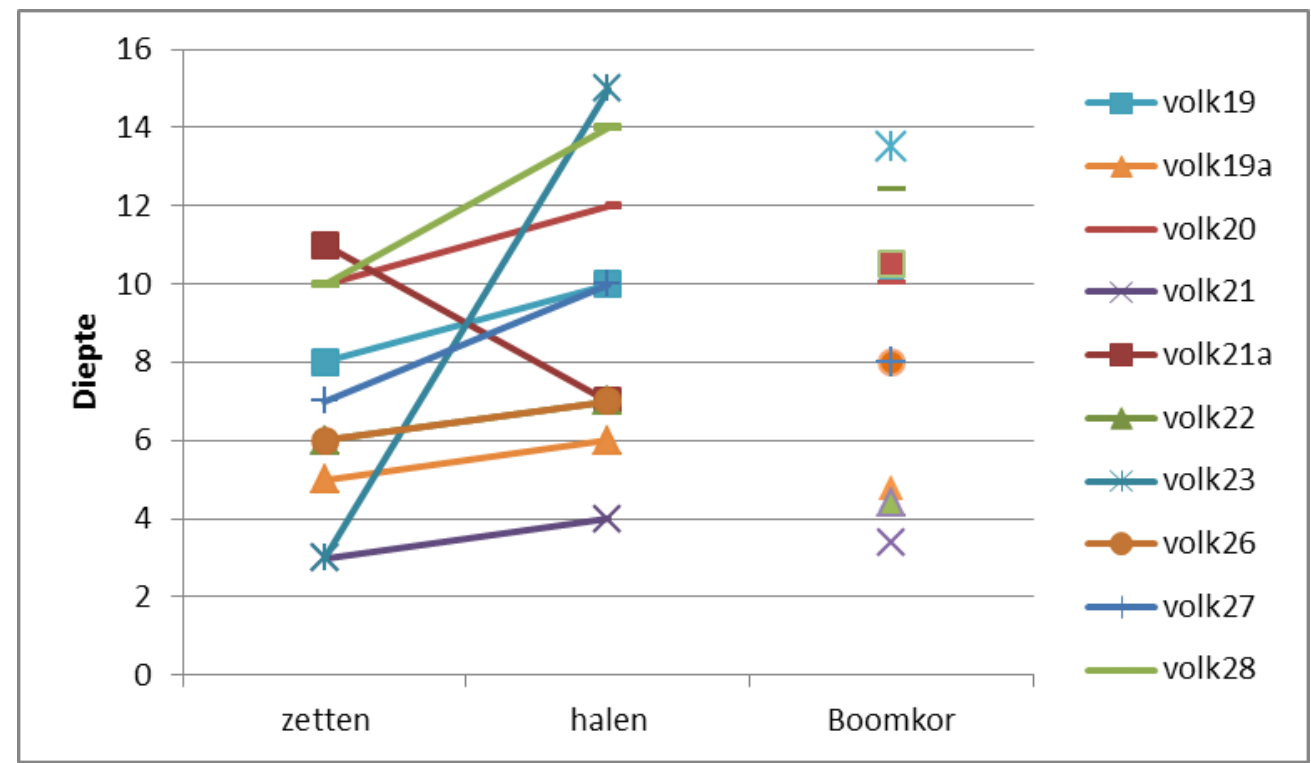

Figuur 3. Verschil in zet- en haaldieptes van de stortkuil en de diepte van de boomkor. NB te dieptes van volk20 en volk21a en van volk26 en volk27 (boomkor) overlappen waardoor deze niet goed zichtbaar zijn in de grafiek. 
Tabel 1. Verschillen tussen de boomkor en stortkuilbemonstering.

\begin{tabular}{|l|l|l|}
\hline variabele & boomkor & stortkuil \\
\hline breedte vistuig & $3 \mathrm{~m}$ & $10 \mathrm{~m}$ (tijdens vissen) \\
\hline maaswijdte & $35,22,20 \mathrm{~mm}$ & $14 \mathrm{~mm}$ \\
\hline vissnelheid & $6 \mathrm{~km} / \mathrm{uur}$ & $4,5 \mathrm{~km} / \mathrm{uur}$ \\
\hline Visafstand & $1000 \mathrm{~m}$ & $1000 \mathrm{~m}$ \\
\hline nauwkeurigheid lengtemetingen & $\begin{array}{l}\text { conform protocol (Sluis et al., } \\
2016)\end{array}$ & 'to the cm below' \\
\hline
\end{tabular}




\section{Resultaten}

Om een vergelijking te maken tussen de drie behandelingen is een analyse in twee stappen uitgevoerd: 1) vaststellen of er verschil is tussen behandelingen en 2) vaststellen welke behandelingen dan van elkaar verschillen. Voor de eerste stap is een 'mixed linear model' gebruikt, met als co-variabele 'behandeling' (boomkor-dag, boomkor-nacht en stortkuil-nacht), per locatie. Dit type model maakt een combinatie van categorische variabelen ("analysis of variance") met continue co-variabelen ('analysis of covariance') mogelijk. Het model is gefit met een 'maximum likelihood estimation' en op basis van de 'likelihood ratio test' (LRT) is de nul hypothese getest. Deze likelihood is een test voor de waarschijnlijkheid dat een hypothese wordt verworpen; er wordt getoetst of er verschillen zijn. Indien met de LRT de hypothese werd verworpen met een significantie niveau van 0.05 is vervolgens een post-hoc 'Tukey Honest significant difference' test gedaan (post-hoc HSD test). Met deze test wordt getoetst welke behandelingen dan van elkaar verschillen. Voor de niet-significante combinaties is geen verdere test gedaan.

\subsection{Aantal soorten}

Het uitgangspunt in de analyse (nul hypothese) is dat geen verschil is tussen de behandelingen (boomkor-dag vs boomkor-nacht; boomkor-dag vs stortkuil-nacht; boomkor-nacht vs stortkuil-nacht). Dat betekent dat geen significante verschillen verwacht worden tussen dag en nacht voor de boomkor en de nachtbemonsteringen van de boomkor en de stortkuil. De vergelijking tussen boomkor-dag en stortkuil-nacht is op basis van twee variabelen, namelijk tijdstip en vistuig, welke daardoor niet te scheiden zijn.

De resultaten op basis van het aantal soorten is weergegeven in Figuur 4. Een grotere afwinking van de diagonaal impliceert een groter verschil tussen behandelingen.

De toegepaste post-hoc HSD test laat zien dat er significant verschil zit in het aantal soorten tussen de stortkuil-nacht en de boomkor-dag (Tabel 2; 2,4 soorten meer in de stortkuil dan in de boomkor). Dit is niet het geval voor de andere twee combinaties.

Tabel 2. Resultaten van de post hoc HSD test van de vergelijking van het aantal soorten per paar.

\begin{tabular}{|l|c|c|}
\hline Vergelijking & $\begin{array}{c}\text { geschatte coëfficiënt } \\
\text { (verschil aantal soorten) }\end{array}$ & $\begin{array}{c}\text { gecorrigeerde } \\
\text { p-waarde }\end{array}$ \\
\hline ST-N versus BK-N & 0.8 & 0.71 \\
\hline BK-D versus BK-N & -1.6 & 0.25 \\
\hline ST-N versus BK-D & 2.4 & $\mathbf{0 . 0 5}$ \\
\hline
\end{tabular}
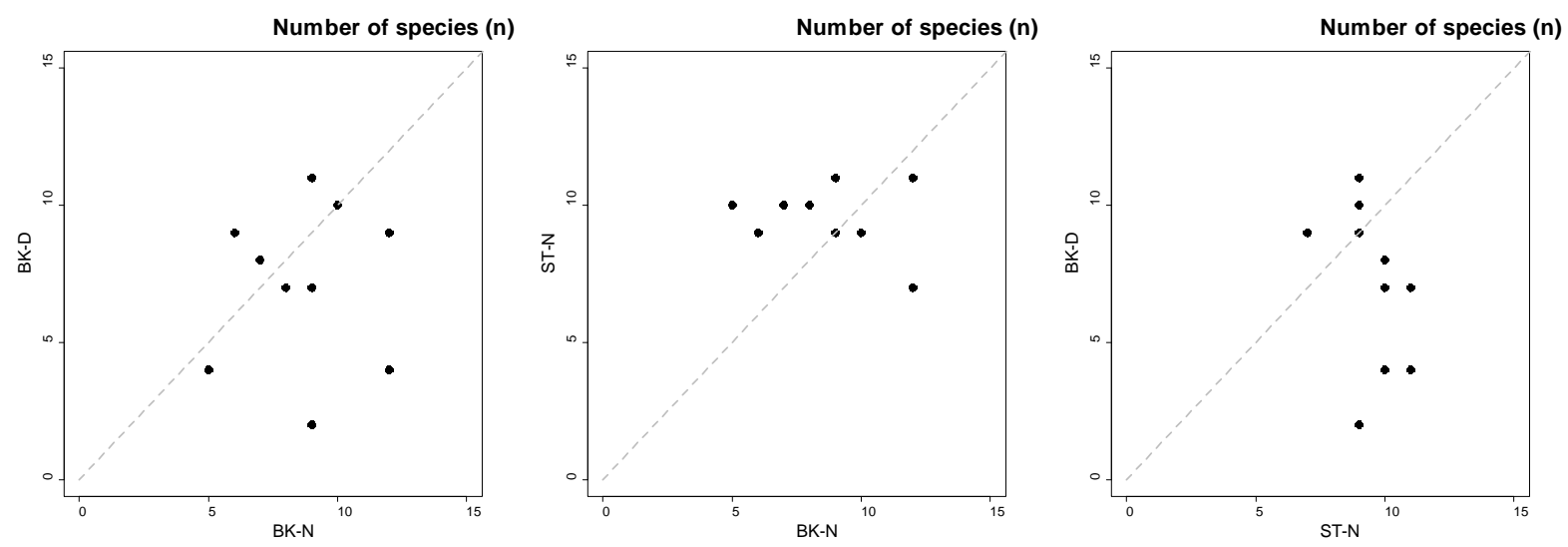


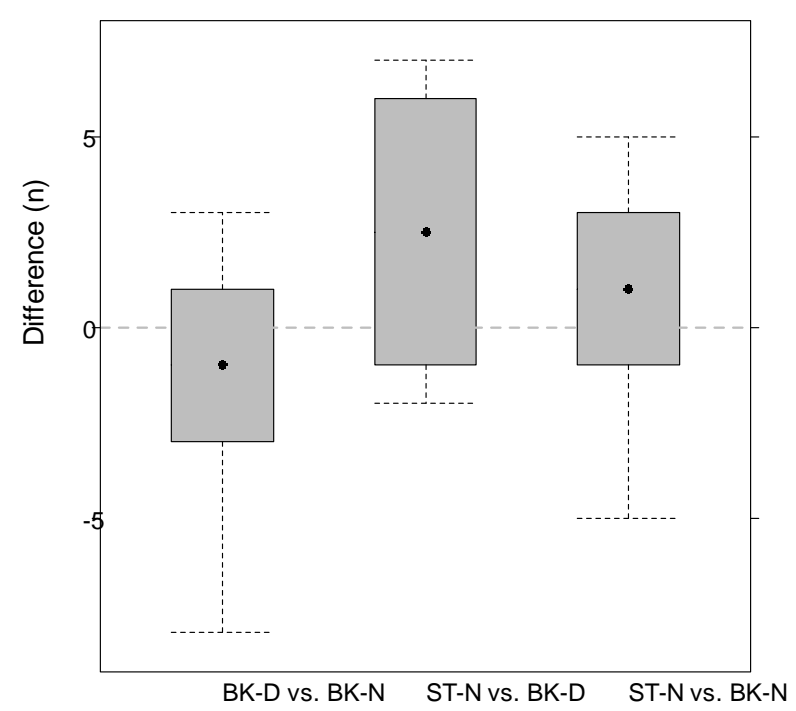

Figuur 4. Het aantal gevangen soorten per behandeling. Bovenste rij: het aantal soorten van de drie behandelingen tegen elkaar uitgezet. Onder: boxplot van het verschil in het aantal soorten.

\subsection{Lengte frequentie}

Voor de vergelijking van de lengte frequenties is een gepaarde Kolmogorov-Smirnov test gebruikt (KS test), welke het verschil in twee verdelingen toetst. Het uitgangspunt (nul hypothese) is dat de lengte frequenties op gelijke wijze verdeeld zijn en dat er geen significante verschillen optreden tussen de dag en nachtvangsten met de boomkor of tussen de vangsten met boomkor en stortkuil.

De KS-test toont aan dat op basis van alle vis de stortkuil-nacht een significant andere lengte frequentie verdeling vangt dan de boomkor (dag en nacht) en dat er ook een significant verschil is tussen boomkor-dag en boomkor-nacht (Tabel 3).

Voor de meest voorkomende soorten (baars, blankvoorn, pos, zwartbekgrondel, spiering, brasem en snoekbaars) zijn de lengtefrequenties van de verschillende behandelingen per soort een vergeleken. Over het algemeen komen de lengte frequenties van boomkor-dag en boomkor-nacht overeen, behalve voor blankvoorn brasem en pos. Voor blankvoorn en brasem vangt de boomkor 's nachts meer grote vis dan overdag. Voor pos wordt deze significante waarde niet onderschreven door een verschil in de cumulatieve lengte opbouw (Bijlage 3). Voor snoekbaars geldt dat er geen significant verschil is in lengte frequentie tussen dag en nacht, maar wel tussen de boomkor (dag en nacht) en de stortkuil.

De stortkuil-nacht laat in het algemeen een significant verschil zien in lengte frequentie verdeling met de boomkor (dag en nacht). Voor de zwartbekgrondel is wel een verschil is gevonden tussen de stortkuil en de boomkor-nacht, maar niet tussen de stortkuil en de boomkor-dag, of tussen dag en nacht bij de boomkor. De lengte frequenties van de zeven vissoorten welke apart zijn geanalyseerd staan in Bijlage 2. 
Tabel 3. Resultaten van de KS-test voor de lengte frequentie verdeling van de hele vangst en voor de zeven meest voorkomende soorten apart. Wanneer de $p$-waarde vetgedrukt is, is het verschil significant.

\begin{tabular}{|c|c|c|}
\hline & vergelijking & p-waarde \\
\hline \multirow[t]{3}{*}{ Alle vis } & BK-D vs BK-N & 0.037 \\
\hline & ST-N vs BK-N & $<0.001$ \\
\hline & ST-N vs BK-D & $<0.001$ \\
\hline \multirow[t]{3}{*}{ Baars } & $B K-D$ vs BK-N & 0.401 \\
\hline & ST-N vs BK-N & $<0.001$ \\
\hline & ST-N vs BK-D & $<0.001$ \\
\hline \multirow[t]{3}{*}{ Blankvoorn } & BK-D vs BK-N & 0.004 \\
\hline & ST-N vs BK-N & 0.002 \\
\hline & ST-N vs BK-D & $<0.001$ \\
\hline \multirow[t]{3}{*}{ Pos } & BK-D vs BK-N & 0.024 \\
\hline & ST-N vs BK-N & $<0.001$ \\
\hline & ST-N vs BK-D & $<0.001$ \\
\hline \multirow[t]{3}{*}{ Zwartbekgrondel } & BK-D vs BK-N & 0.391 \\
\hline & ST-N vs BK-N & 0.012 \\
\hline & ST-N vs BK-D & 0.159 \\
\hline \multirow[t]{3}{*}{ Spiering } & $B K-D$ vs BK-N & 0.698 \\
\hline & ST-N vs BK-N & 0.025 \\
\hline & ST-N vs BK-D & $<0.001$ \\
\hline \multirow[t]{3}{*}{ Brasem } & $B K-D$ vs BK-N & $<0.001$ \\
\hline & ST-N vs BK-N & 0.782 \\
\hline & ST-N vs BK-D & $<0.001$ \\
\hline \multirow[t]{3}{*}{ Snoekbaars } & BK-D vs BK-N & 0.215 \\
\hline & ST-N vs BK-N & $<0.001$ \\
\hline & ST-N vs BK-D & $<0.001$ \\
\hline
\end{tabular}

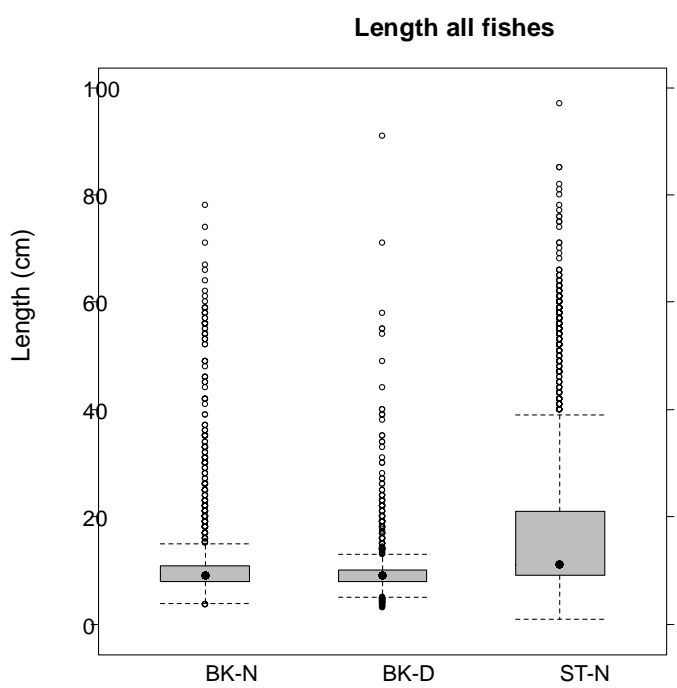

Figuur 5. Gemiddelde lengte voor alle vis voor de drie behandelingen.

Figuur 5 en Figuur 6 laten een grote spreiding in lengtes zien, waarbij de stortkuil meer grote vis vangt. Het percentage vis groter dan $40 \mathrm{~cm}$ loopt voor de verschillende behandelingen uiteen (stortkuil-nacht: $11 \%$; boomkor-nacht 3\% en boomkor-dag 1\%). Ook vangt de stortkuil vis kleiner dan $3 \mathrm{~cm}$, wat niet het geval is voor de boomkor. 


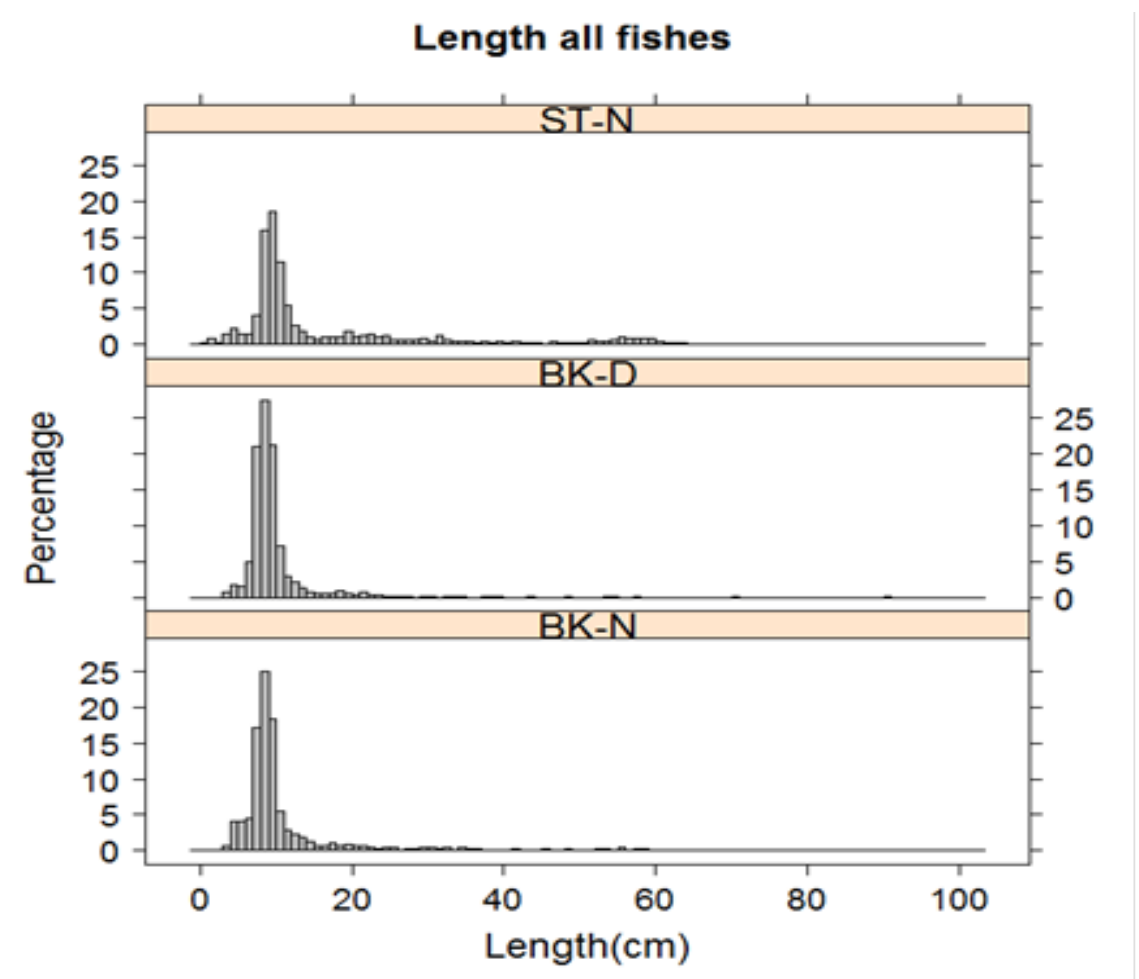

Figuur 6. Histogram van de lengte verdeling voor de drie behandelingen (alle vis gezamenlijk).

Naast de lengte frequentie verdeling is gekeken naar de cumulatieve verdeling van aantallen en biomassa over lengte (Figuur 7). De 'empirical cumulative distribution function' (ECDF) (Figuur 7, links) is een aanvulling op de KS-test. Hoe beter het resultaat op de diagonaal ligt, des te evenwichtiger is de aantallen verdeeld over de lengte range. Bij een steile lijn worden de aantallen gedomineerd door kleinere vis en indien de snelste stijging meer rechts zit door grotere vis. Voor alle vis geeft Figuur 7 (links) weer dat de vangsten voor boomkor-dag en boomkor-nacht wat minder gedomineerd is door grotere vis dan de stortkuil. 

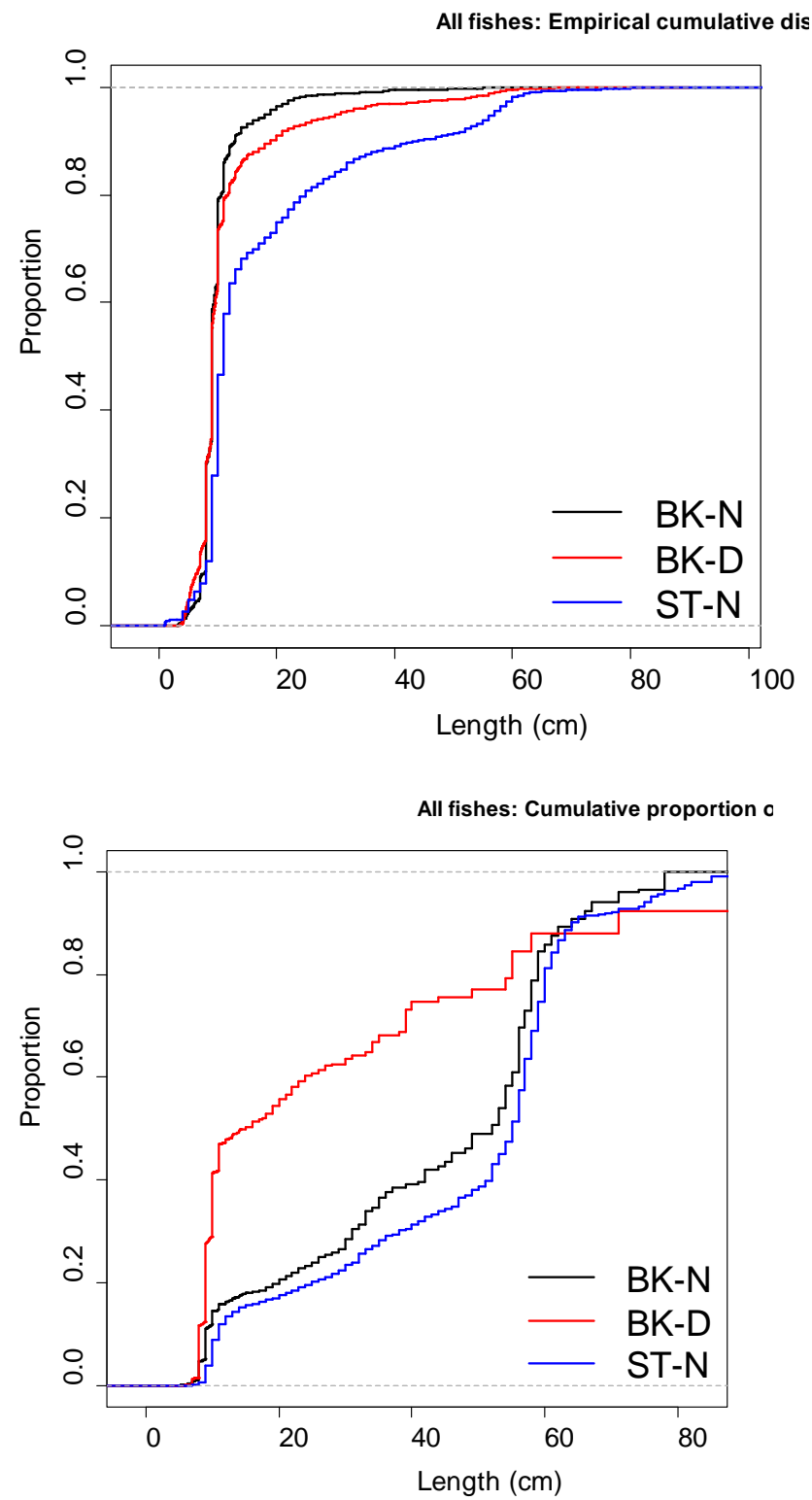

Figuur 7. Cumulatieve verdeling van aantallen over lengte (boven) en cumulatieve verdeling van biomassa over lengte (onder) voor de drie behandelingen, voor alle vis.

Voor de cumulatieve biomassa verdeling laat Figuur 7 (rechts) zien dat de vangst van de boomkor-dag afwijkt van de andere twee behandelingen omdat 's nachts meer grote vis gevangen wordt dan overdag (Figuur 6). Net als voor de lengte frequentie verdeling geldt dat ook hier verschillen tussen soorten optreden (Bijlage 3). Verschillen tussen soorten springen echter meer in het oog dan verschillen tussen de behandelingen. Bij blankvoorn zijn er wel grote verschillen te zien in de cumulatieve biomassa verdeling, omdat 's nachts meer grote vis wordt gevangen dan overdag.

\subsection{CPUE (Catch per unit effort)}

Om een goede vergelijking te kunnen doen van de biomassa per hectare zijn de CPUE's (catch per unit effort) getransformeerd (log transformatie), zodat de resultaten niet afwijken van een normale verdeling. Figuur 8 geeft een beeld van de overeenkomsten in CPUE tussen de behandelingen.

De post hoc HSD test (Tabel 4) voor alle vissoorten gezamenlijk geeft de indicatie dat met de stortkuil een hogere CPUE wordt gevangen dan met de boomkor-dag en dat er geen hogere CPUE wordt gevangen dan met de boomkor-nacht $(p=0.16)$. Met de boomkor-nacht wordt ook een hogere CPUE gevangen dan de boomkor-dag. Dit is in lijn met de grotere vissen die 's nachts worden gevangen. 
Ook hier geldt weer dat er verschillen tussen soorten zijn, waarbij de verschillen tussen dag en nacht vooral optreden bij soorten met een groter lengte range (Bijlage 4).

Tabel 4. Resultaten van de post hoc HSD test van de vergelijking van CPUE per paar voor alle vis en voor de meest voorkomende soorten. Wanneer de $p$-waarde vetgedrukt is, is het verschil significant.

\begin{tabular}{|c|c|c|c|}
\hline & Vergelijking & $\begin{array}{l}\text { Geschatte coëfficiënt } \\
\text { (verschil in biomassa) }\end{array}$ & $\begin{array}{c}\text { gecorrigeerde } \\
\text { p-waarde }\end{array}$ \\
\hline \multirow[t]{3}{*}{ Alle vis } & $\mathrm{ST}-\mathrm{N}$ versus $\mathrm{BK}-\mathrm{N}$ & 0.43 & 0.16 \\
\hline & $B K-D$ versus $B K-N$ & -0.54 & 0.06 \\
\hline & ST-N versus BK-D & 0.98 & $<0.01$ \\
\hline \multirow[t]{3}{*}{ Brasem } & $\mathrm{ST}-\mathrm{N}$ versus BK-N & 0.74 & 0.07 \\
\hline & BK-D versus $B K-N$ & -0.84 & 0.04 \\
\hline & ST-N versus BK-D & 1.58 & $<0.01$ \\
\hline \multirow[t]{3}{*}{ Snoekbaars } & $\mathrm{ST}-\mathrm{N}$ versus $\mathrm{BK}-\mathrm{N}$ & 0.11 & 0.87 \\
\hline & $B K-D$ versus $B K-N$ & -0.72 & $<0.01$ \\
\hline & ST-N versus BK-D & 0.83 & $<0.01$ \\
\hline \multirow[t]{3}{*}{ Blankvoorn } & $\mathrm{ST}-\mathrm{N}$ versus $\mathrm{BK}-\mathrm{N}$ & 0.42 & 0.23 \\
\hline & BK-D versus $B K-N$ & -0.19 & 0.74 \\
\hline & ST-N versus BK-D & 0.61 & 0.05 \\
\hline
\end{tabular}
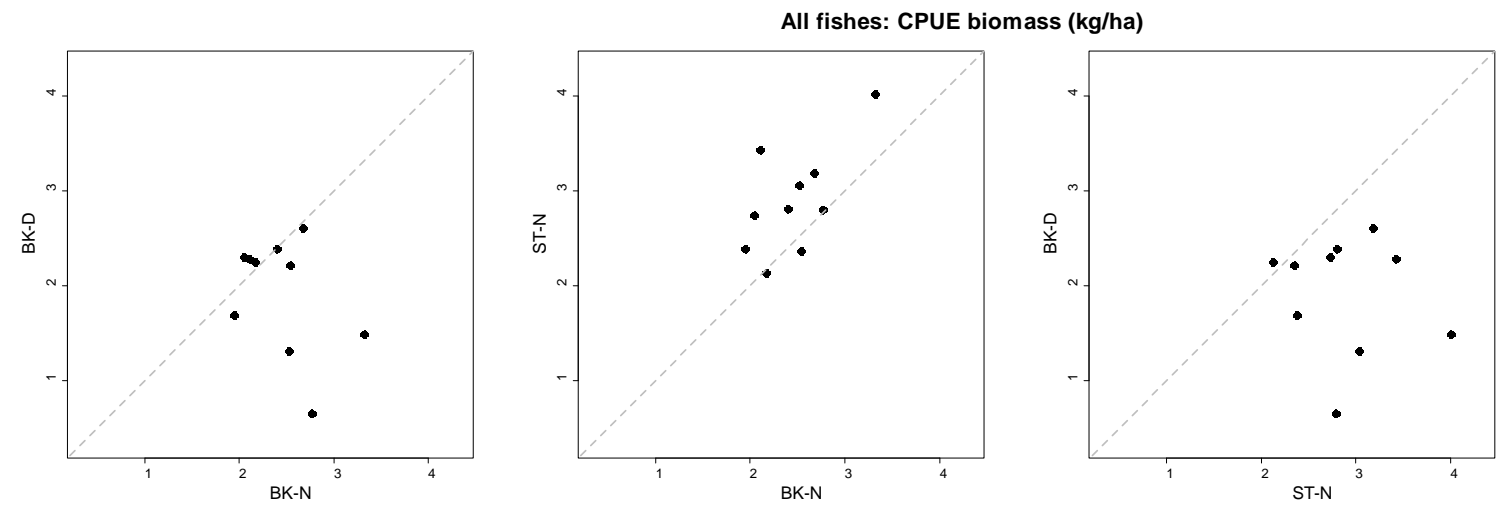

All fishes: CPUE biomass (kg)

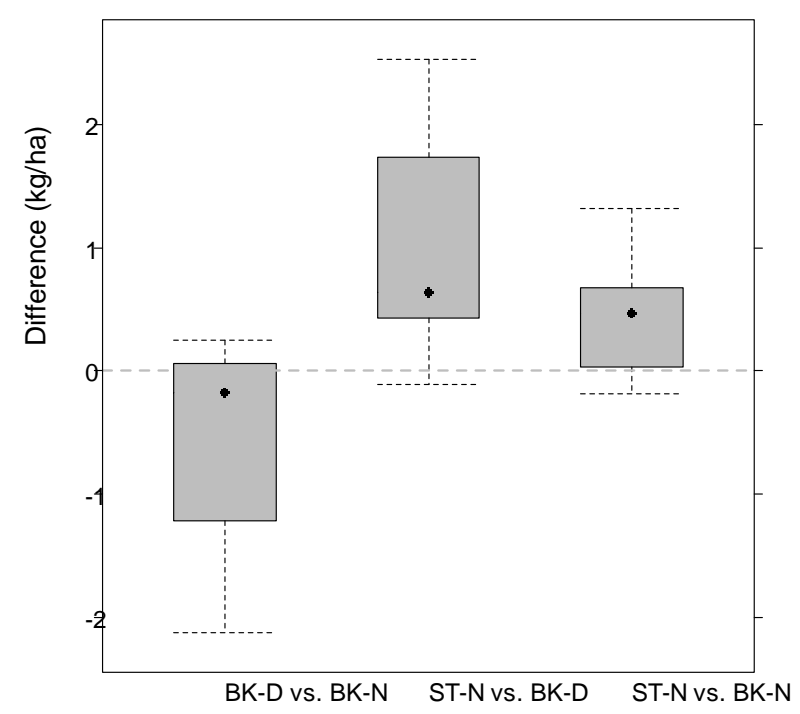

Figuur 8. De CPUE (kg/ha) per behandeling voor alle vis samen. Bovenste rij: CPUE van de drie behandelingen tegen elkaar uitgezet. Onder: boxplot van het verschil in CPUE. 


\section{$4 \quad$ EKR scores}

Op verzoek van Rijkswaterstaat heeft Wageningen Marine Research (WMR) de EKR score berekend voor het Volkerak, waar afgelopen najaar met verschillende technieken (combinatie van vistuig en visserij gedurende de dag/nacht) is gevist op tien locaties. De gemiddelde CPUE van de tien trekken per 'behandeling' staan weergegeven in Tabel 4. Soorten met een opvallend verschil in biomassa tussen de drie behandelingen waren brasem, snoek en snoekbaars.

Ten behoeve van de EKR berekening worden vissoorten opgesplitst in gilden. Snoek valt in twee gilden (eurytoop en plantminnend) en brasem en snoekbaars in één gilde (eurytoop). Soorten uit de gilden 'exoten' en 'O2-tolerante vissen' zijn niet gevangen in de dertig trekken. Snoekbaars wordt ten behoeve van de EKR berekeningen opgesplitst in maats en ondermaats.

De behandeling met de boomkor overdag geeft de hoogste EKR score (Figuur 9). Ter informatie zijn de gegevens van de jaren 2008, 2011 en 2014 ook weergegeven. Deze gegevens zijn niet één op één te vergelijken met de drie behandelingen (meer trekken, andere locaties, etc.), maar het is duidelijk dat de EKR waardes tussen de jaren verschillen.

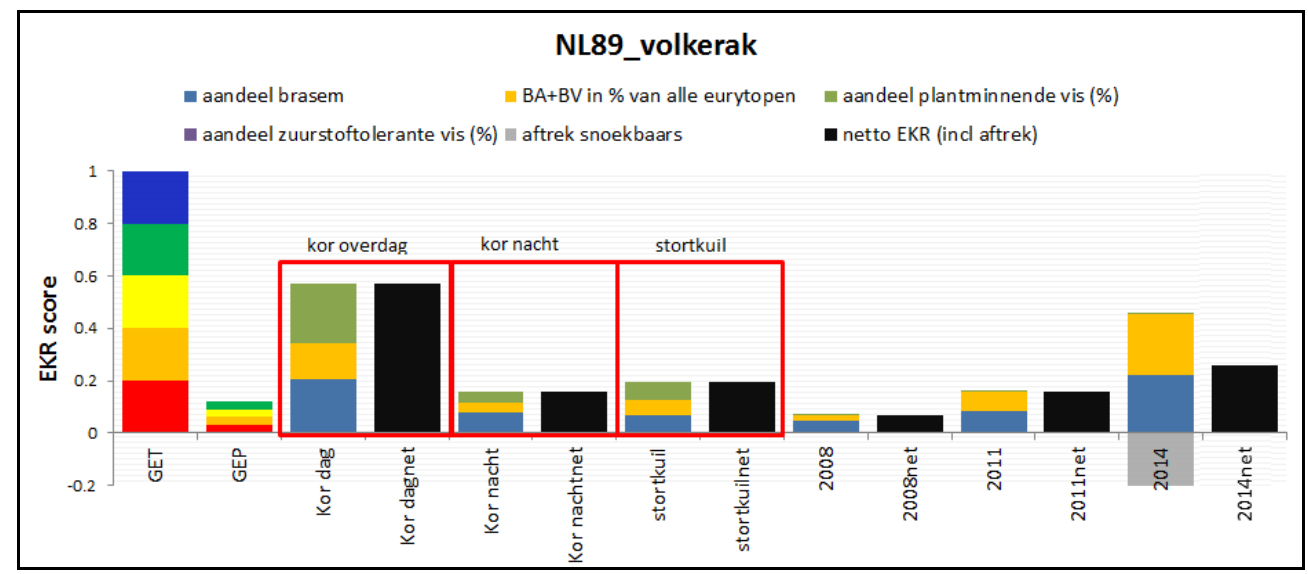

Figuur 9. EKR score voor de verschillende tuigen en periode.

Het effect van de vangst van de verschillende soorten op de EKR score is doorberekend (Figuur 10). Indien er overdag met de kor een gelijk aantal brasem was gevangen als 's nachts, zou de EKR score ook gelijk waardig zijn geweest. Indien dat met snoekbaars of snoek het geval zou zijn, heeft dit een minder sterk effect op de EKR score dan voor brasem.

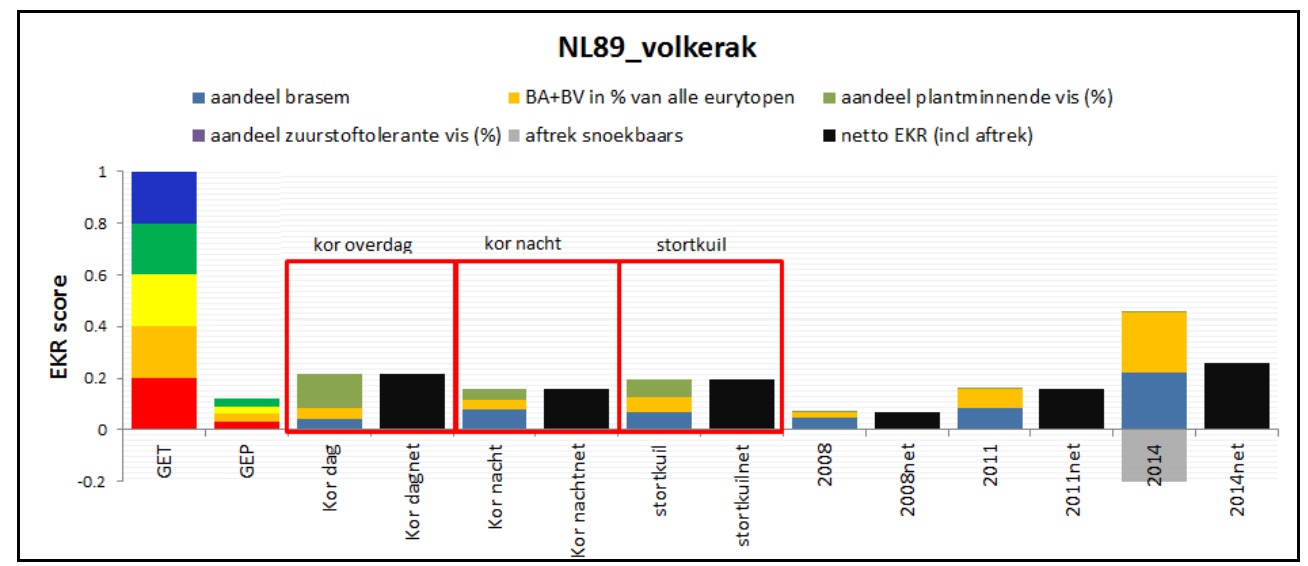

Figuur 10. EKR score waarbij de 'kor overdag' een gemiddelde gelijk aantal brasem toegekend heeft gekregen als de andere samples: $71.8 \mathrm{KG} / \mathrm{ha}$.

\section{Brasem}

In de nachttrekken (boomkor en stortkuil) is meer brasem gevangen dan overdag. Met name de brasem heeft een sterke invloed op de EKR score en dan met name de deelmaatlat voor (1) 'aandeel brasem', maar ook indirect in (2) 'aandeel BA+BV van alle eurytope' en (3) 'aandeel plantminnende vis' (Tabel 6). 
De eerste deelmaatlat (1) wordt direct beïnvloed door de hogere brasem vangsten 's nachts. Voor een goede score moet het aandeel brasem ten opzichte van de overige soorten beperkt zijn.

Bij de tweede deelmaatlat (2) heeft het grote aandeel brasem 's nachts ook een negatief effect omdat het aandeel gewenste soorten (baars en blankvoorn) ten opzichte van brasem klein is. Ook hier is de EKR score hoger bij minder brasem. Een zelfde redenatie geldt voor de derde deelmaatlat (3). Ook hier is leidt een toename van het aandeel brasem tot een lagere EKR score (Figuur 10).

Er zijn geen zuurstof tolerante soorten gevangen, maar ook hier zou hetzelfde kunnen gelden. De verhouding tussen een grote brasem vangst en de indicator soort(en) levert een lage EKR score op indien er veel brasem wordt gevangen.

\section{Snoekbaars}

De invloed van de grotere hoeveelheid snoekbaars in de nachtvangsten op voor de deelmaatlatten (2) en (3) is min of meer hetzelfde als voor brasem geldt. Ook hier geldt dat de indicator soorten BA+BV of plantminnende soorten naar verhouding beperkt aanwezig zijn omdat de snoekbaars in biomassa goed vertegenwoordigd is. Het effect is echter niet zo sterk als voor brasem.

Tabel 6. Score van deelmaatlatten per behandeling na weging per deelmaatlat. De eindbeoordeling is in de laatste rij gezet inclusief een eventuele aftrek voor de 'snoekbaars deelmaatlat'.

\begin{tabular}{|l|l|l|l|l|l|l|}
\hline & BK-dag & BK-nacht & Stortkuil-nacht & 2008 & 2011 & 2014 \\
\hline Aandeel brasem & 0.20 & 0.08 & 0.07 & 0.05 & 0.09 & 0.22 \\
\hline BA+BV in\% van alle eurytopen & 0.14 & 0.04 & 0.06 & 0.02 & 0.07 & 0.23 \\
\hline Aandeel plantminnende vis (\%) & 0.23 & 0.05 & 0.07 & 0.00 & 0.00 & 0.01 \\
\hline Aandeel zuurstoftolerante vis (\%) & 0.00 & 0.00 & 0.00 & 0.00 & 0.00 & 0.00 \\
\hline Aftrek snoekbaars & 0.00 & 0.00 & 0.00 & 0.00 & 0.00 & -0.20 \\
\hline EKR endbeoordling (inc. Aftrek) & 0.57 & 0.16 & 0.19 & 0.07 & 0.16 & 0.26 \\
\hline
\end{tabular}




\section{$5 \quad$ Discussie}

\subsection{Bemonstering en analyse}

Om het effect van doorzicht op de vangbaarheid van vis in het Volkerak in te schatten is vergelijkend gevist. Hierbij is met de standaard boomkor overdag en 's nachts gevist, en met de stortkuil 's nachts, ervan uitgaande dat bij trekken in het donker het doorzicht geen rol speelt en bij trekken overdag wel. $\mathrm{Er}$ is geen analyse gedaan van vangsten op basis van doorzicht zelf. Een verandering in vangst 's nachts ten opzichte van vangsten overdag kan verschillende oorzaken hebben waarvan doorzicht er één is naast bijvoorbeeld temperatuur en voedselbeschikbaarheid. Daarnaast kan veranderd gedrag (mogelijk verschillende per soort en vislengte) ook effect hebben op de vangst.

Voor een volledige statistische vergelijking tussen boomkor en stortkuil zou ook een behandeling met de stortkuil overdag moeten zijn uitgevoerd.

\subsection{Verschil boomkor overdag en 's nachts}

Op basis van de huidige gegevens lijkt er licht verschil te zijn tussen de boomkor bemonsteringen overdag en 's nachts. Er is geen verschil in het aantal soorten. Er is geen verschil in CPUE voor alle soorten samen. Voor de individuele soorten geldt dat er 's nachts een hogere CPUE is gevonden voor brasem en snoekbaars, voor de andere soorten is dit niet het geval. Er is wel verschil tussen de boomkor-dag en de boomkor-nacht in de cumulatieve biomassa verdeling, maar op soortniveau is dit wisselend.

Verschillen in de lengteverdeling zijn voor de meest voorkomende soorten niet significant, ook niet voor snoekbaars, welke een grote lengte range heeft. $\mathrm{Er}$ is een significant verschil in lengte verdeling voor alle vis samen. Er is ook een verschil in lengte voor brasem, welke een grote invloed heeft op de EKR score via de gebruikte $\mathrm{kg} / \mathrm{ha}$ in de deelmaatlat, daar er meer grote en minder kleine brasem 's nachts wordt gevangen. Wanneer meer trekken worden uitgevoerd kan met grotere zekerheid worden bepaald of er een verschil is tussen overdag en 's nachts vissen met de boomkor.

\subsection{Verschil stortkuil en boomkor}

Over de hele visvangst genomen, is er verschil tussen de stortkuil en de boomkor overdag, zowel in CPUE, lengte-verdeling als het aantal soorten. De stortkuil vangt kleinere vis dan de boomkor (ook 's nachts) en meer grote vis. Er is geen verschil in lengte-verdeling tussen stortkuil en kor (nacht) voor brasem, wel voor snoekbaars. Dit verschil voor snoekbaars heeft echter geen effect op de deelmaatlat 'aftrek snoekbaars', maar werkt licht door op deelmaatlatten 'BA+BV in \% van alle eurytopen' en 'aandeel plantminnende vis'.

$\mathrm{Er}$ is geen significant verschil gevonden in CPUE (alle vissoorten gecombineerd en individuele soorten) tussen de tuigen tijdens de nachtbemonstering, ook niet voor soorten met een grotere lengte range. Aangezien de CPUE positief beïnvloed wordt door grotere vis is het aannemelijk dat er ook voor aantallen per hectare geen verschil zal zijn.

\subsection{Aanpassen van de bemonsteringsmethodiek}

Vergelijking van bemonsteringsmethodieken leidt automatisch tot de vraag welke methodiek 'de meest geschikte' is. Om deze afweging goed te kunnen maken is allereerst een heldere vraagstelling noodzakelijk die het doel van de monitoring specificeert. Daarna kan de afweging worden gemaakt welke methodiek de meest geschikte is om de vraagstelling te beantwoorden. Hieronder staan enkele mogelijke afwegingen voor en gevolgen van een mogelijke wisseling van bemonsteringsmethodiek in het Volkerak. 
Een significant verschil in lengte frequentie veroorzaakt door het vangen van kleinere vis zal geen aanleiding zijn om de bemonsteringsmethodiek te veranderen, daar dit weinig toevoegt aan het beeld van de populatie-opbouw. Een verschil door het vangen van grotere vis, zou wel aanleiding kunnen geven de bemonsteringsmethodiek te veranderen indien dat een ander beeld geeft van de populatieopbouw.

Aanpassing van de bemonsteringsmethodiek heeft zeer waarschijnlijk gevolgen voor de verhoudingen tussen de diverse indicatorsoorten (o.a. brasem en snoekbaars) in de vangst, leidend tot een veranderde de EKR-score. De resultaten in deze studie leveren hiervoor een voorbeeld. Of de verschillende monitoringstrategieën ook een structurele en vergelijkbare verhouding tussen de soorten zoals in de huidige studie opleveren kan op basis van dit korte experiment niet met zekerheid worden aangetoond omdat de EKRs van de bemonsteringen in de afgelopen tien jaar ook wisselen. Zo was de EKR score in de reguliere monitoring in 2014 ook anders dan die van 2008 en 2011. Daarnaast is de invloed van brasem op de EKR score afhankelijk van het water type. Immers, bij meren, zoals het Volkerak, wordt het aandeel brasem op basis van $\mathrm{kg} /$ ha meegeteld terwijl dit voor rivieren op basis is van aantallen/ha. Dat betekent dat bij gelijke aantallen maar een andere lengte verdeling de score in meren wel sterk wordt beïnvloed maar in rivieren een stuk minder.

Om te bepalen of het huidig gebruikte tuig, de boomkor, volstaat voor de bemonstering van de visstand, is het van belang om het doel van de bemonstering in ogenschouw te nemen, te weten aanleveren van informatie over de toestand van de visgemeenschap in het Volkerak via de EKR. De deelmaatlatten uit de EKR worden niet beïnvloed door sec de grootte van de vangsten. Het vangen van meer vis is daarmee geen reden tot aanpassing van de bemonsteringsmethodiek omdat de populatie opbouw en een trend daar niet mee verandert. Aangezien de EKR deelmaatlatten zijn gebaseerd op biomassa catch per unit effort, kan het verschil in lengteverdeling wel een reden zijn voor een aanvullende bemonstering. Verschillen in lengteverdeling (meer grote, grotere, meer kleine, kleinere vis) leiden immers tot een ander beeld van de populatie opbouw. Vanuit EKR perspectief leiden met name de verschillende lengteverdelingen van brasem tot een verandering in de EKR score. Deze studie laat zien dat brasem en daarmee de EKR score gevoelig is voor het tijdstip van bemonsteren, 's nachts vissen met de boomkor leidt tot een lagere EKR score dan overdag vissen met de boomkor. De vangst van snoekbaars is daarentegen meer afhankelijk van het gebruikte tuig en niet zozeer van het tijdstip van bemonsteren. Kiezen voor een tuig of tijdstip is daarmee bewust kiezen voor het anders bemonsteren van soorten.

Bij een eventuele uitbreiding van de bemonsteringsmethodiek zullen ook praktische overwegingen moeten worden meegenomen. De MWTL-bemonstering wordt in het najaar en in het voorjaar uitgevoerd waarbij de kans op slecht weer en hoog water aanwezig is. Het is daarom noodzakelijk dat de gekozen methodiek daar op berekend is om verlet en uitval van stations te voorkomen. Daarnaast is het van belang dat de scheepvaart de veiligheid en uitvoering van het programma zo min mogelijk beïnvloedt. Het weer en de scheepvaart speelden tijdens deze bemonstering parten in de uitvoering. De bemonsteringsmethodiek zal geschikt moeten zijn voor het diepteprofiel in het Volkerak.

Indien het wenselijk is de reeds bestaande meerjarige monitoringsreeks in het Volkerak ook in de toekomst te gebruiken, zal de invloed van een eventuele wijziging van bemonsteringsmethodiek van tevoren moeten worden gekwantificeerd. Gebeurt dit niet dan is er sprake van een trendbreuk en zullen de tot nu toe verzamelde data minder waardevol worden. 


\section{Conclusies}

1. Wat is het verschil in vangst van de boomkor in termen van hoeveelheden, lengte samenstelling en aantal soorten vis tussen de dag- en nachtbemonstering?

Voor alle vis samen is er geen verschil in CPUE ( $\mathrm{kg} / \mathrm{ha})$ gevonden. Alleen voor brasem en snoekbaars is de CPUE hoger 's nachts dan overdag. $\mathrm{Er}$ is geen verschil in het aantal soorten gevonden. $\mathrm{Er}$ is geen verschil in lengte frequentie verdeling voor alle soorten samen. $\mathrm{Er}$ is wel een verschil in lengte frequentie verdeling voor blankvoorn, pos en brasem.

2. Wat is het verschil in vangst in termen van hoeveelheden, lengte samenstelling en aantal soorten vis tussen de boomkor en de stortkuil (alleen nachttrekken)?

Voor alle vis samen en voor individuele soorten is er geen verschil in CPUE $(\mathrm{kg} / \mathrm{ha})$ gevonden. De stortkuil vangt meer soorten dan de boomkor. Er is een verschil in lengte frequentie verdeling tussen stortkuil en boomkor (nacht) op basis van alle soorten samen. Dit geldt ook voor baars, blankvoorn, pos, zwartbekgrondel, spiering en snoekbaars.

3. Wat is het effect van tuig en tijdstip op de EKR score van het waterlichaam? De deelmaatlatten 'aandeel brasem', 'BA+BV in \% van alle eurytopen' en 'aandeel plantminnende vis' scoren hoger voor de boomkor overdag dan 's nachts. De eindscore is hoger voor de boomkor overdag dan 's nachts. De deelmaatlatten 'aandeel brasem', 'BA+BV in \% van alle eurytopen' en 'aandeel plantminnende vis' scoren vergelijkbaar voor stortkuil en boomkor ('s nachts), en de eindscore voor de stortkuil is slechts 0.03 hoger.

Deze studie laat zien dat brasem en daarmee de EKR score gevoelig is voor het tijdstip van bemonsteren, 's nachts vissen met de boomkor leidt tot een lagere EKR score dan overdag vissen met de boomkor. De vangst van snoekbaars is daarentegen meer afhankelijk van het gebruikte tuig en niet zozeer van het tijdstip van bemonsteren. Kiezen voor een tuig of tijdstip is daarmee bewust kiezen voor het anders bemonsteren van soorten. 


\section{$7 \quad$ Kwaliteitsborging}

Wageningen Marine Research beschikt over een ISO 9001:2008 gecertificeerd kwaliteitsmanagementsysteem (certificaatnummer: 187378-2015-AQ-NLD-RvA). Dit certificaat is geldig tot 15 september 2018. De organisatie is gecertificeerd sinds 27 februari 2001. De certificering is uitgevoerd door DNV Certification B.V. 


\section{Literatuur}

M.T. van der Sluis, N.S.H Tien, A.B. Griffioen, O.A. van Keeken, E. van Os-Koomen,

K.E. van de Wolfshaar, J.A.M. Wiegerinck, M. Lohman (2016), Toestand vis en visserij in de zoete

Rijkswateren 2015; Deel II: Methoden. Wageningen, Wageningen UR (University \& Research centre), IMARES rapport C16/115. 


\section{Verantwoording}

Rapport nummer:

$\mathrm{C} 048 / 17$

Projectnummer:

4316100076

Dit rapport is met grote zorgvuldigheid tot stand gekomen. De wetenschappelijke kwaliteit is intern getoetst door een collega-onderzoeker en het verantwoordelijk lid van het managementteam van Wageningen Marine Research

Akkoord:

Ing. I.J . de Boois

Onderzoeker

Handtekening:

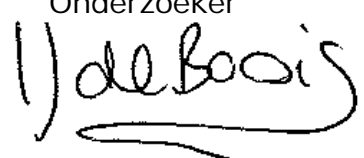

Datum:

30 mei 2017

Akkoord:

Drs. J. Asjes

Manager Integratie

Handtekening:

Datum:

30 mei 2017 


\section{Bijlage 1: a priori power analyse}

Tabel 1. Resulting number of samples required of the power analysis, where power, significance level and the correlation are assumptions, but the variance is based on Volkerak data from 2010-2013.

\begin{tabular}{|r|r|r|r|r|}
\hline \multicolumn{1}{|c|}{ correlation } & \multicolumn{1}{|c|}{$\begin{array}{c}\text { No. sample } \\
\text { required }\end{array}$} & \multicolumn{2}{c|}{$\begin{array}{c}\text { Power } \\
\text { level }\end{array}$} \\
\hline 0.3 & 1.2 & 24 & 0.8 & 0.05 \\
\hline 0.5 & 1.2 & 13 & 0.8 & 0.05 \\
\hline 0.7 & 1.2 & 6 & 0.8 & 0.05 \\
\hline 0.3 & 1.4 & 32 & 0.8 & 0.05 \\
\hline 0.5 & 1.4 & 17 & 0.8 & 0.05 \\
\hline 0.7 & 1.4 & 8 & 0.8 & 0.05 \\
\hline 0.3 & 1.6 & 22 & 0.8 & 0.05 \\
\hline 0.5 & 1.6 & 9 & 0.8 & 0.05 \\
\hline 0.7 & 1.6 & 52 & 0.8 & 0.05 \\
\hline 0.3 & 1.8 & 27 & 0.8 & 0.05 \\
\hline 0.5 & 1.8 & 11 & 0.8 & 0.05 \\
\hline 0.7 & 1.8 & 63 & 0.8 & 0.05 \\
\hline 0.3 & 2 & 33 & 0.8 & 0.05 \\
\hline 0.5 & 2 & 13 & 0.8 & 0.05 \\
\hline 0.7 & 2 & & & \\
\hline & & 41 & 0.8 & 0.8 \\
\hline
\end{tabular}




\section{Bijlage 2: Lengte vergelijking per soort}

Tabel. Samenvatting van de lengte verdeling voor alle vis samen voor elke behandeling.

\begin{tabular}{|l|l|l|l|}
\hline Alle vis & Minimum (cm) & Maximum (cm) & Mediaan (cm) \\
\hline BK-N & 3.6 & 78.0 & 9.0 \\
\hline BK-D & 3.1 & 91.0 & 9.0 \\
\hline ST-N & 3.0 & 97.0 & 11.0 \\
\hline
\end{tabular}

Lengte verdeling en frequentie van de vijf meest voorkomende soorten, zoals gebruikt in de KS-test. Length Baars

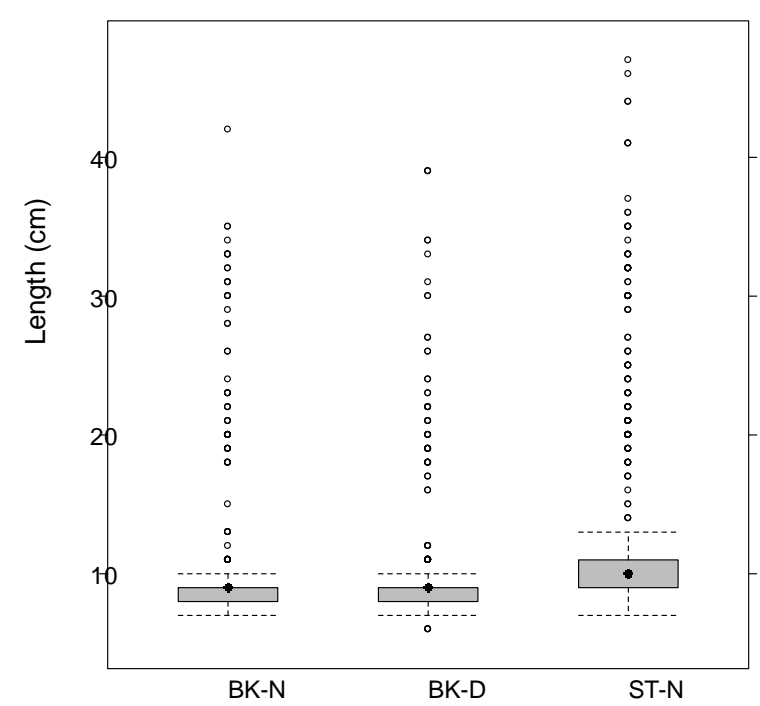

Length Baars

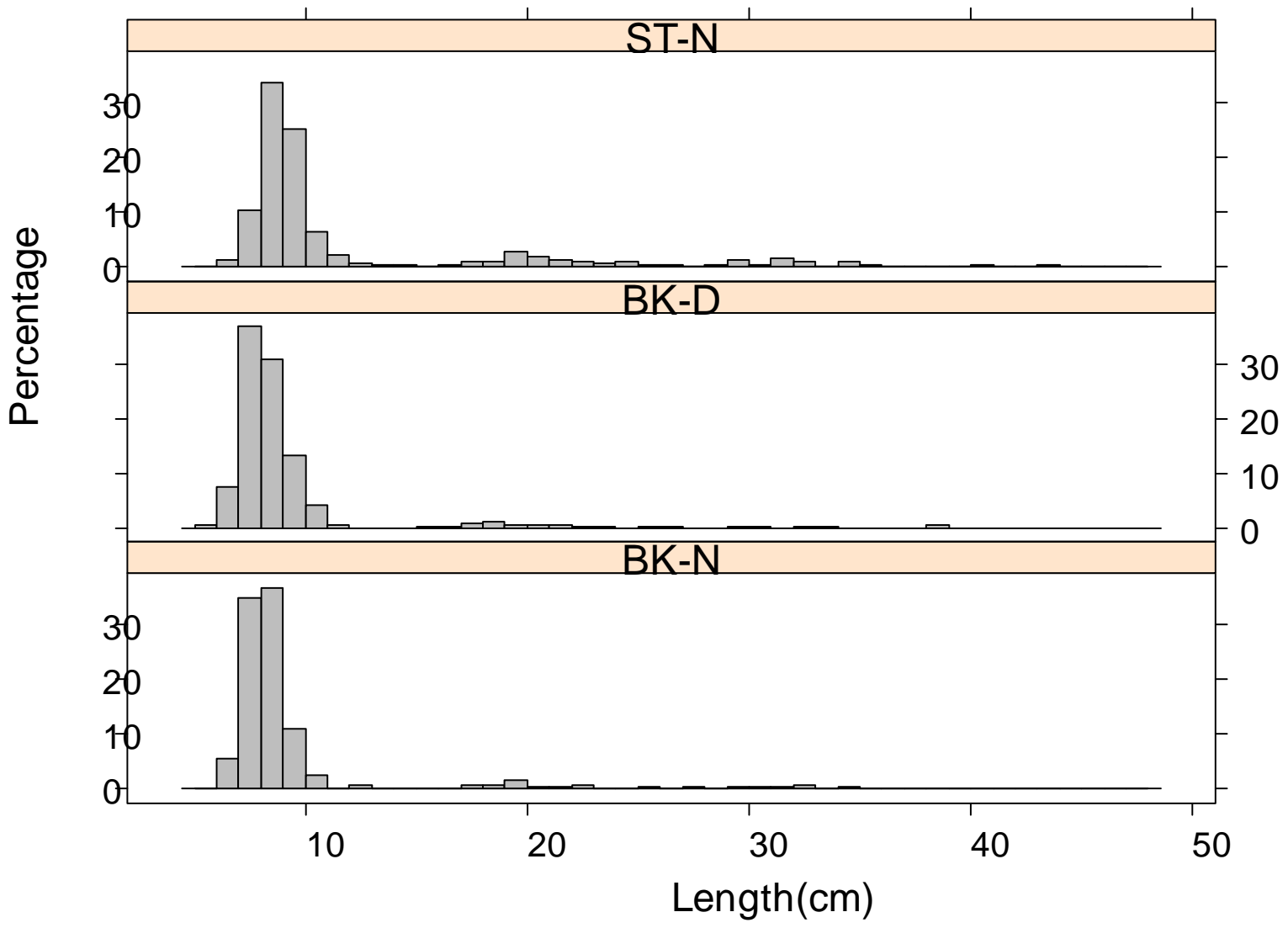




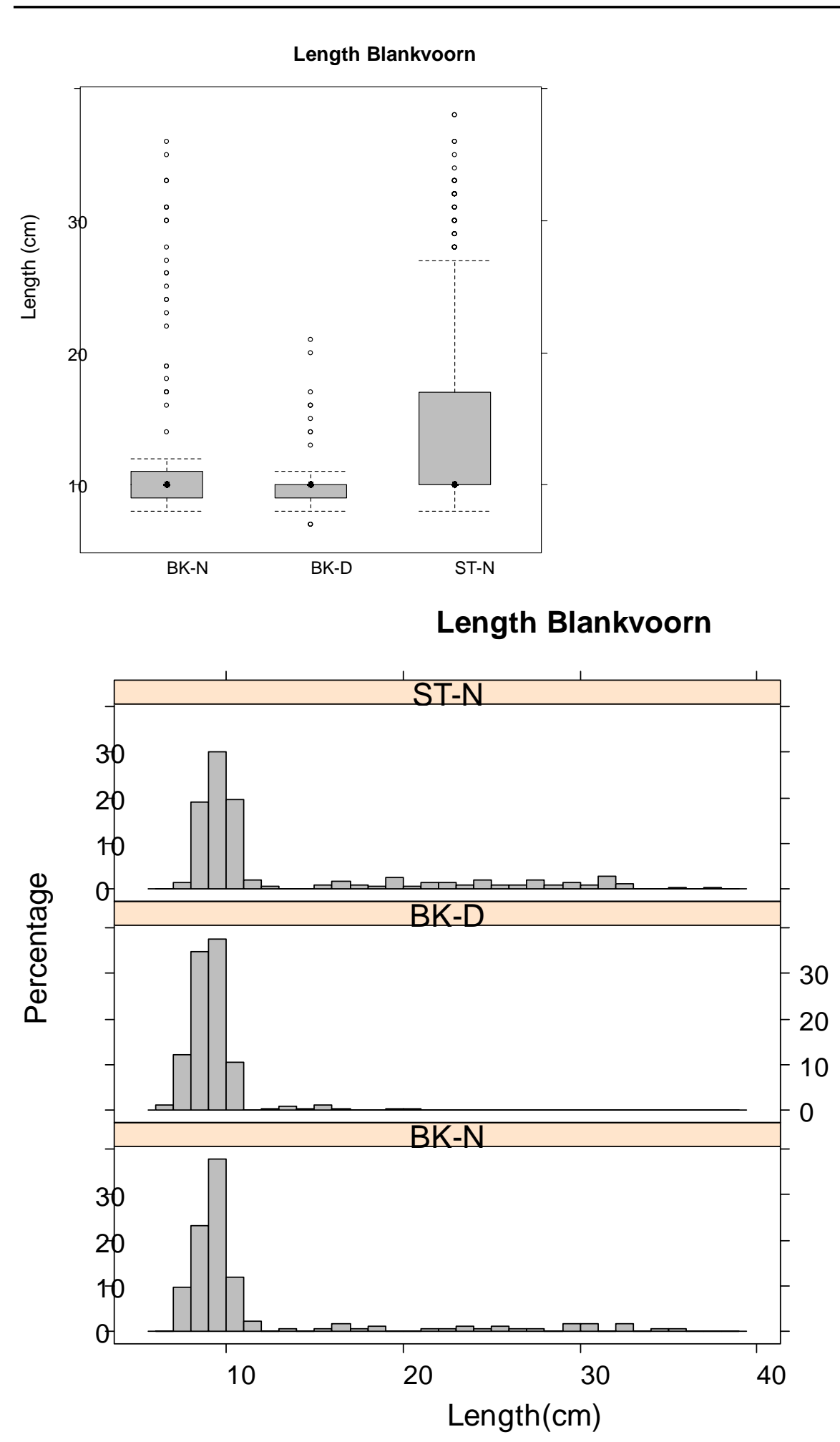


Length Pos

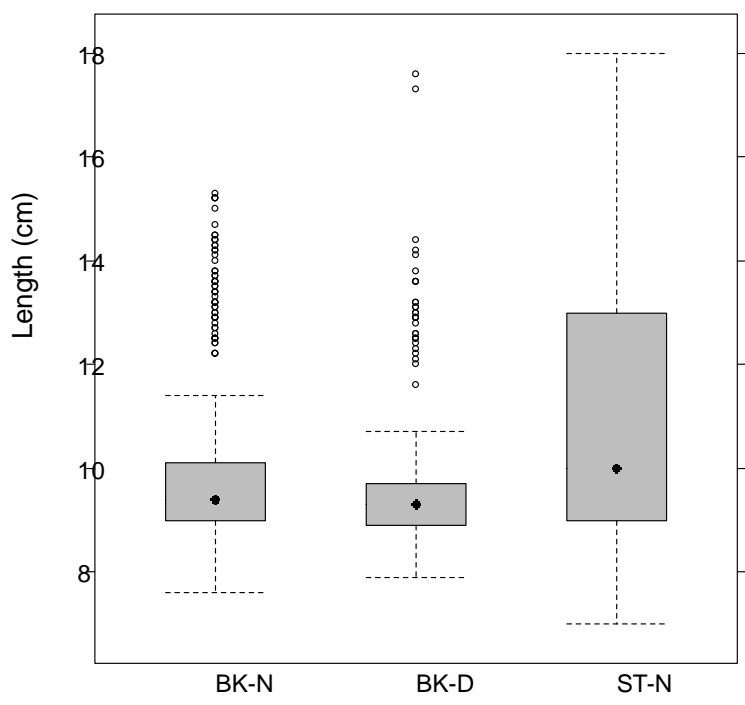

\section{Length Pos}

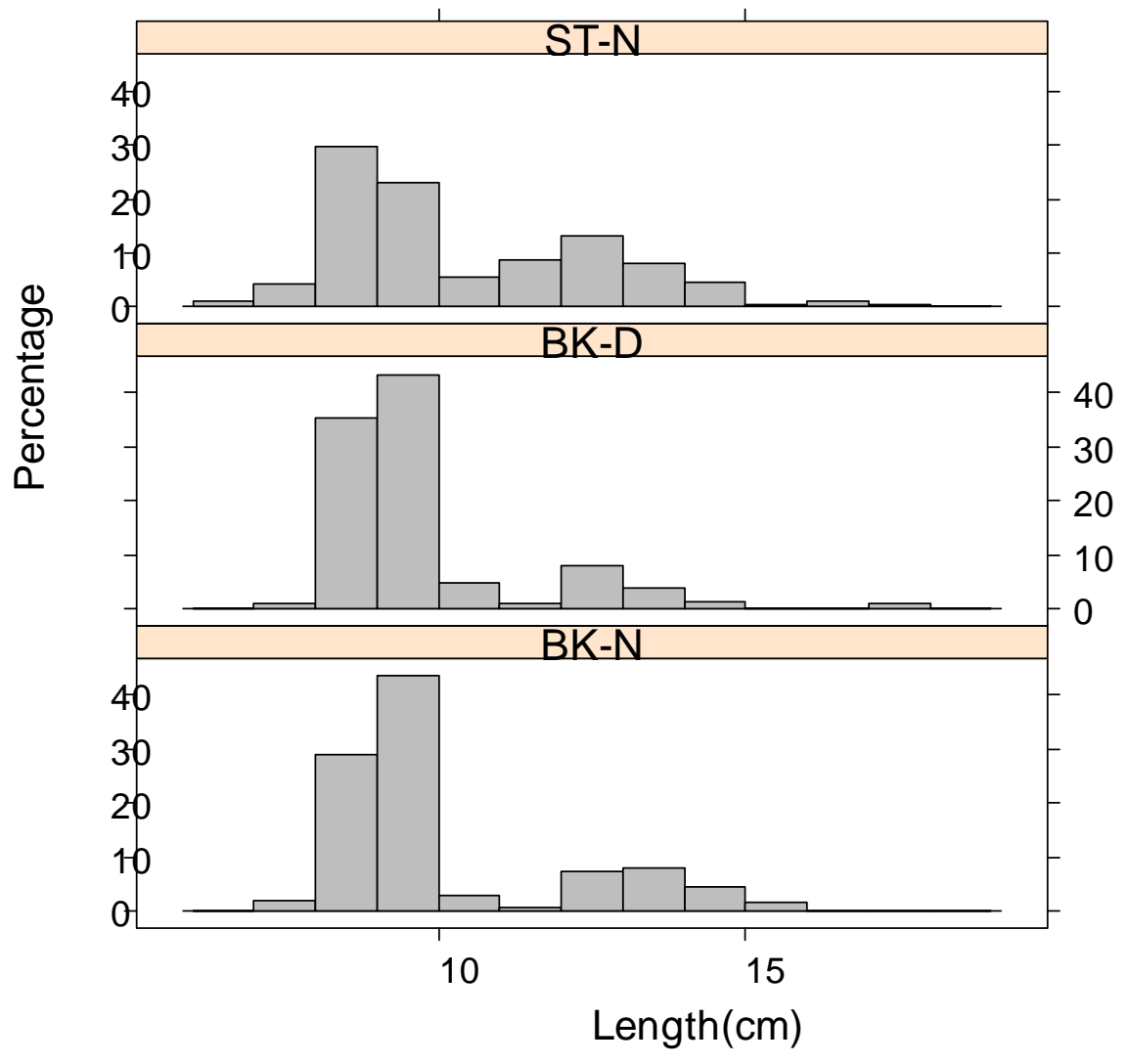




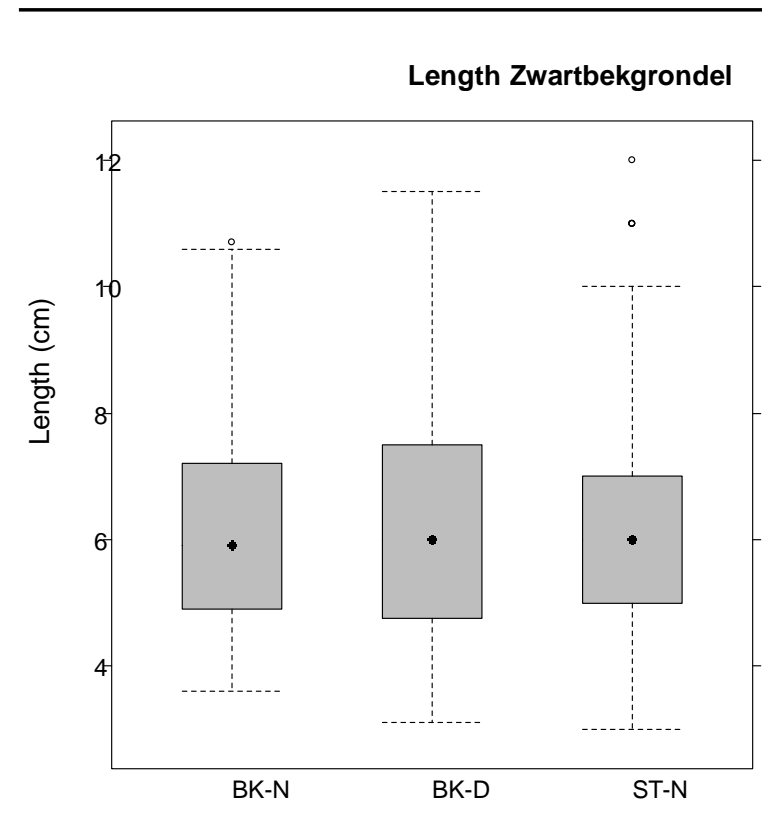

\section{Length Zwartbekgrondel}

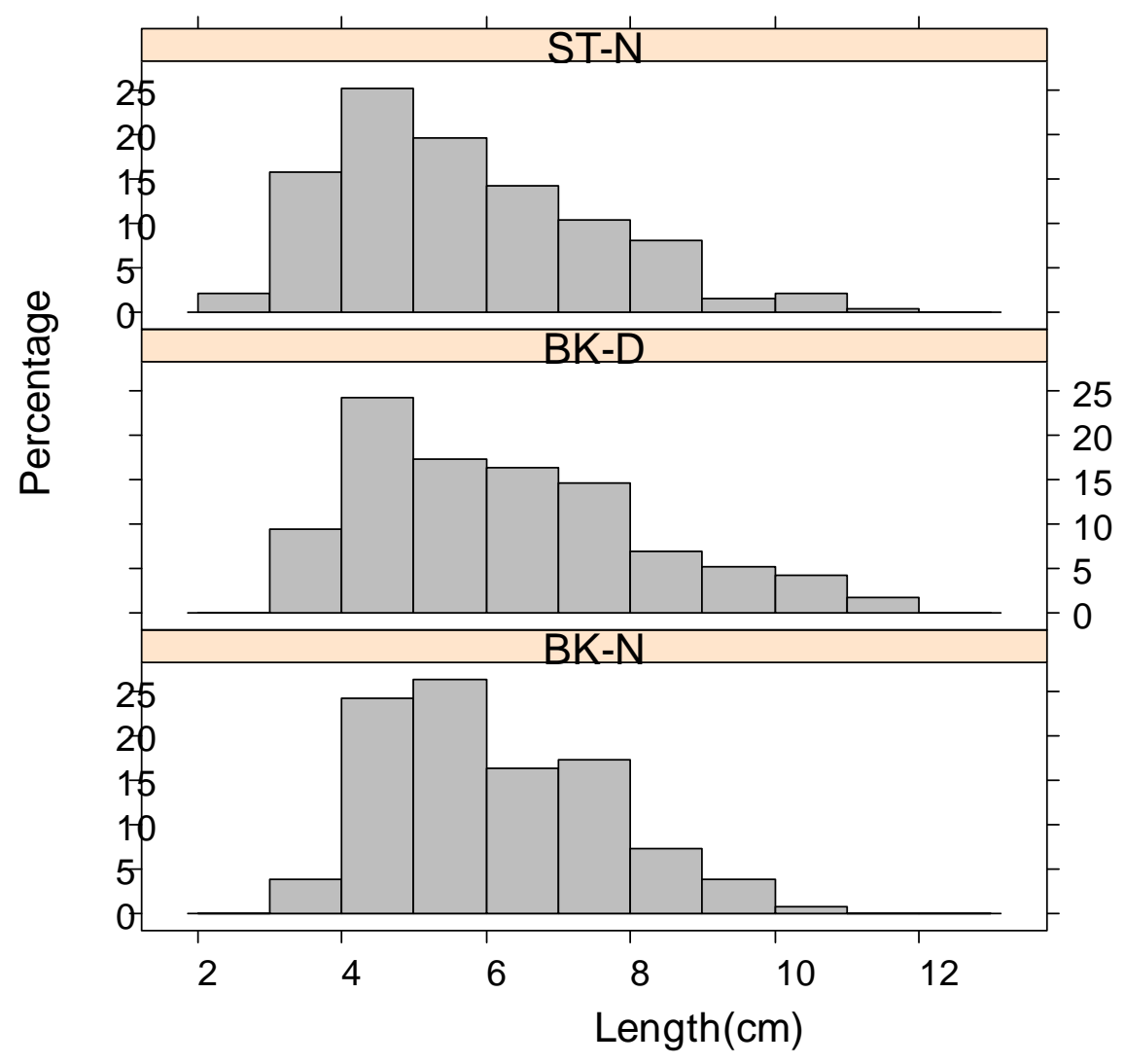




\section{Length Spiering}

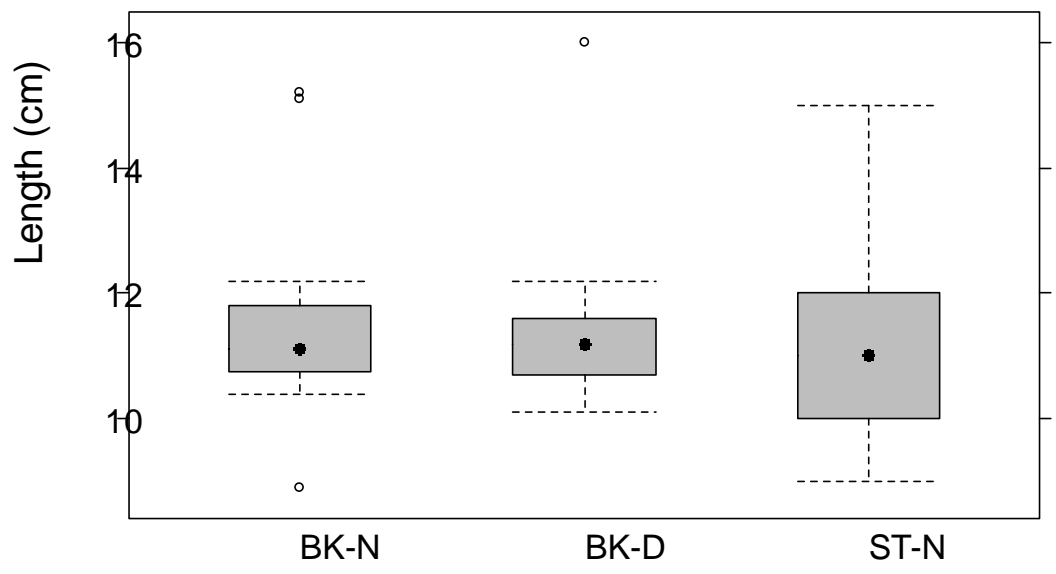

\section{Length Spiering}

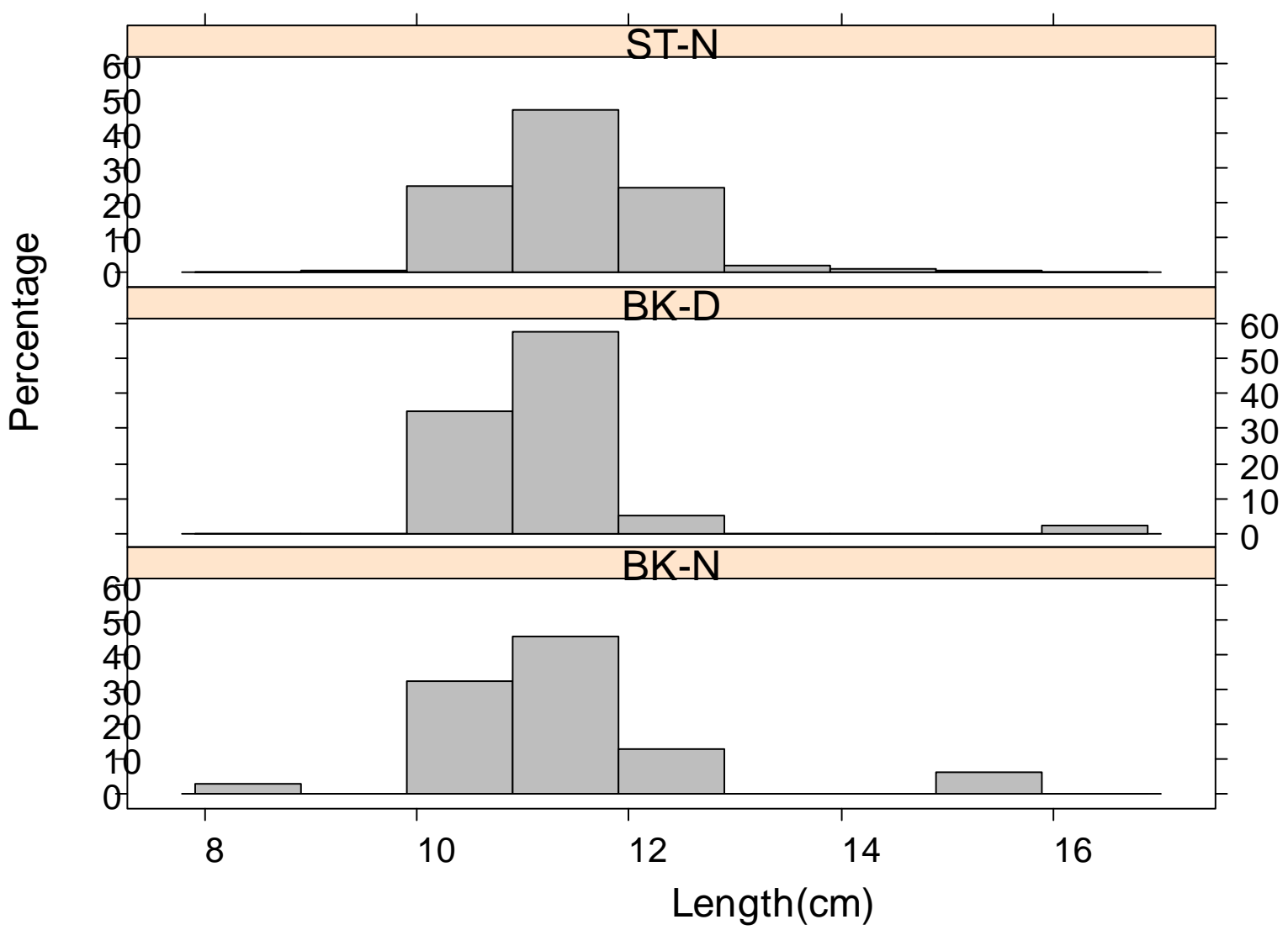




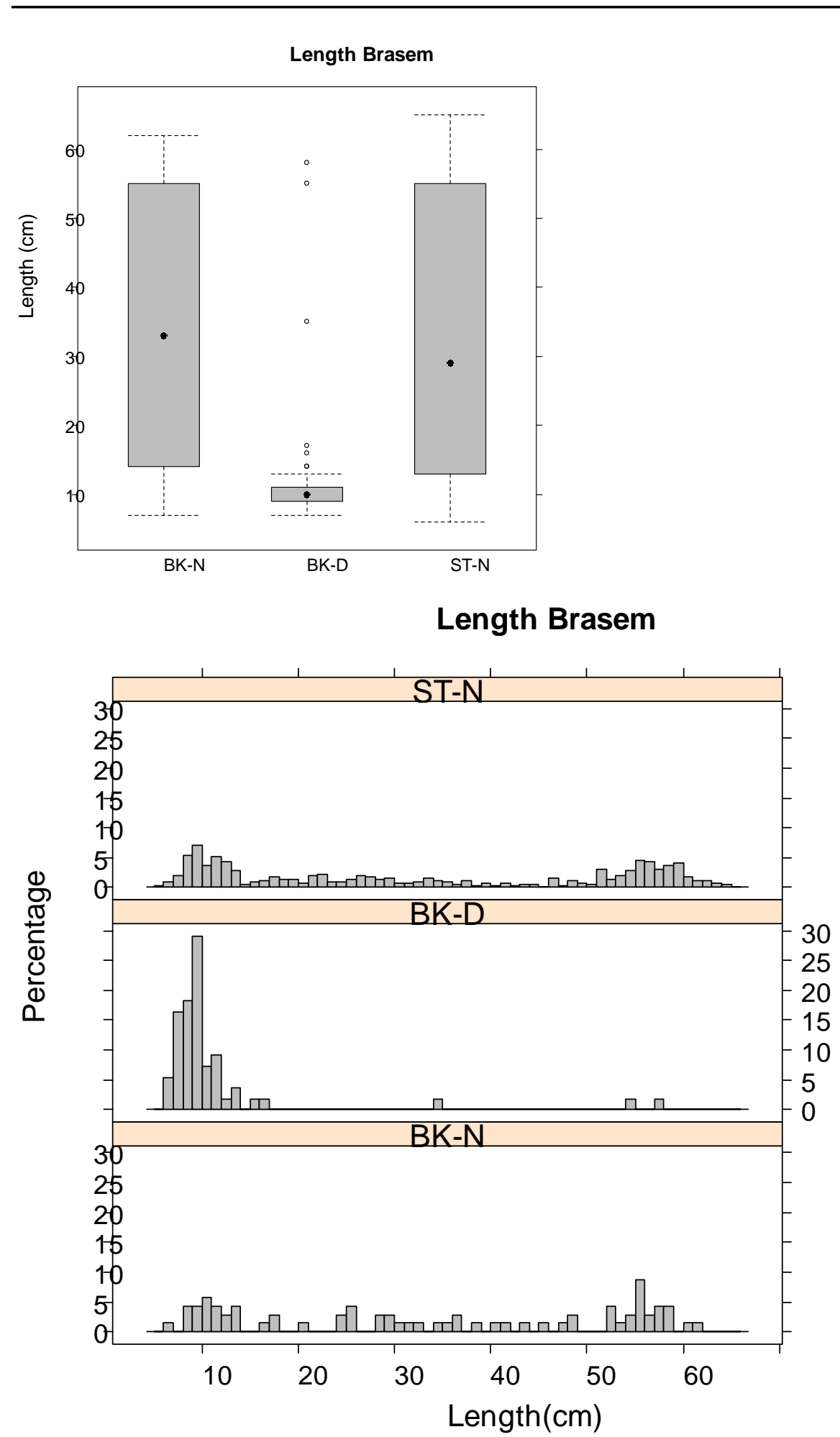


Length Snoekbaars

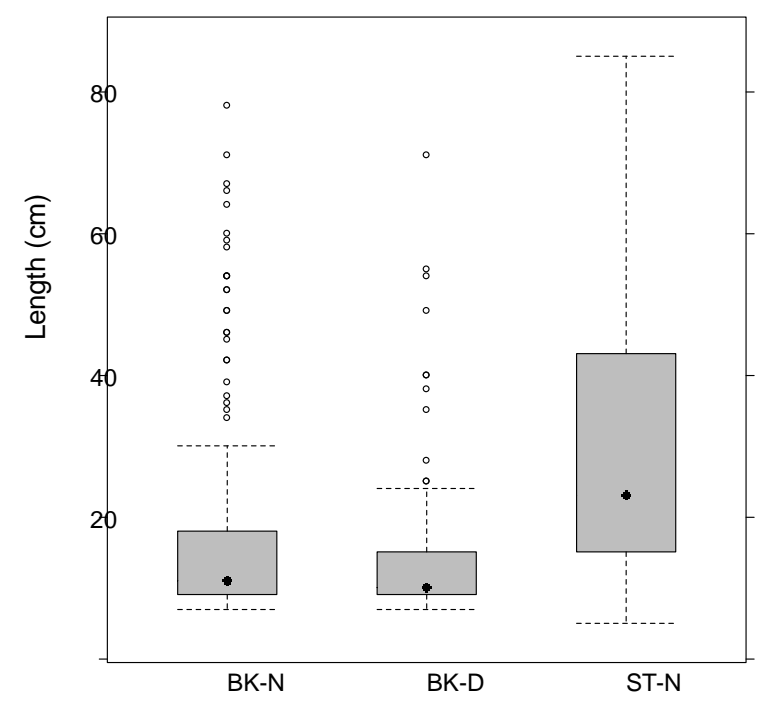

\section{Length Snoekbaars}

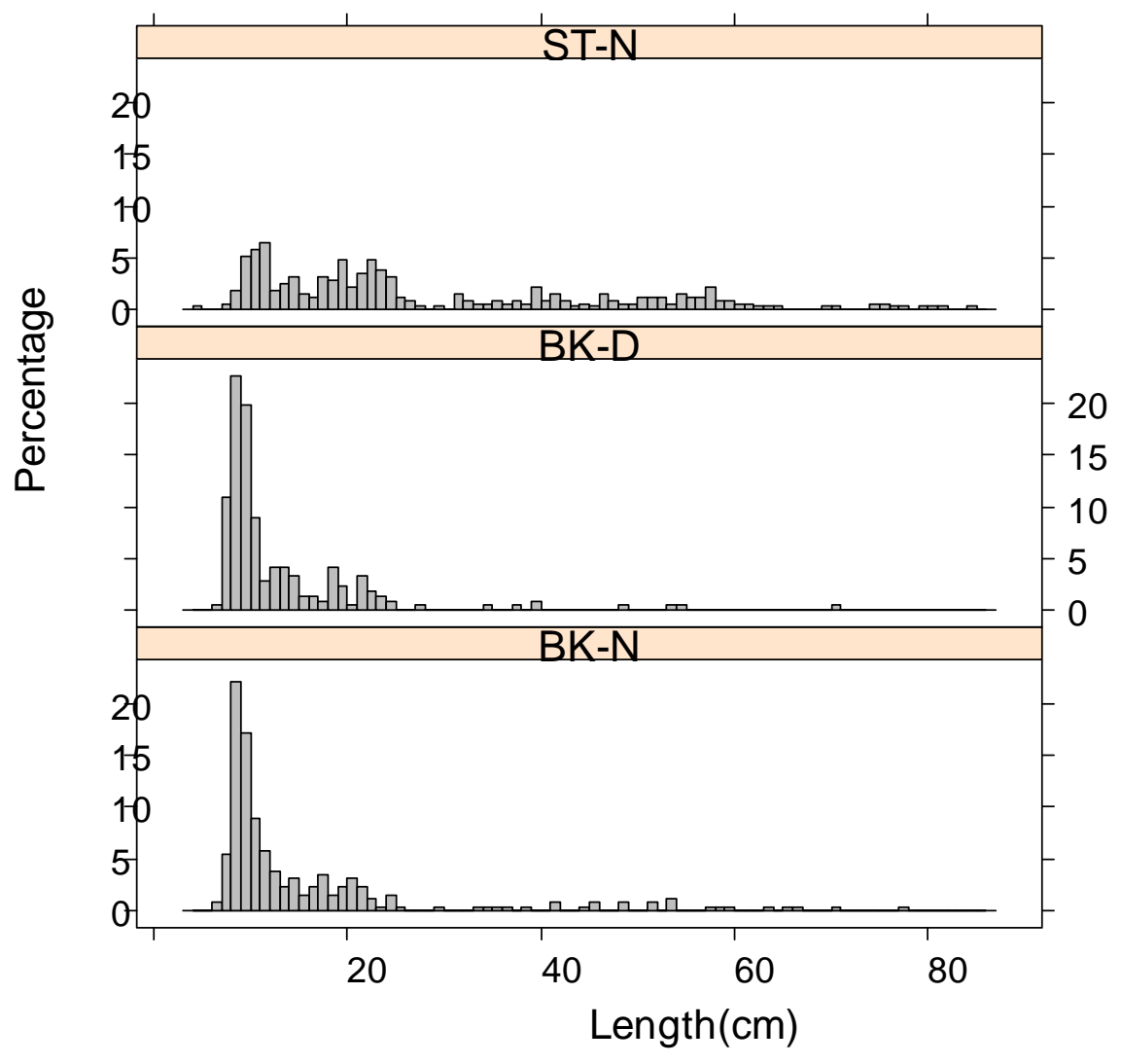




\section{Bijlage 3: Cumulatieve vergelijking op lengte, per soort}
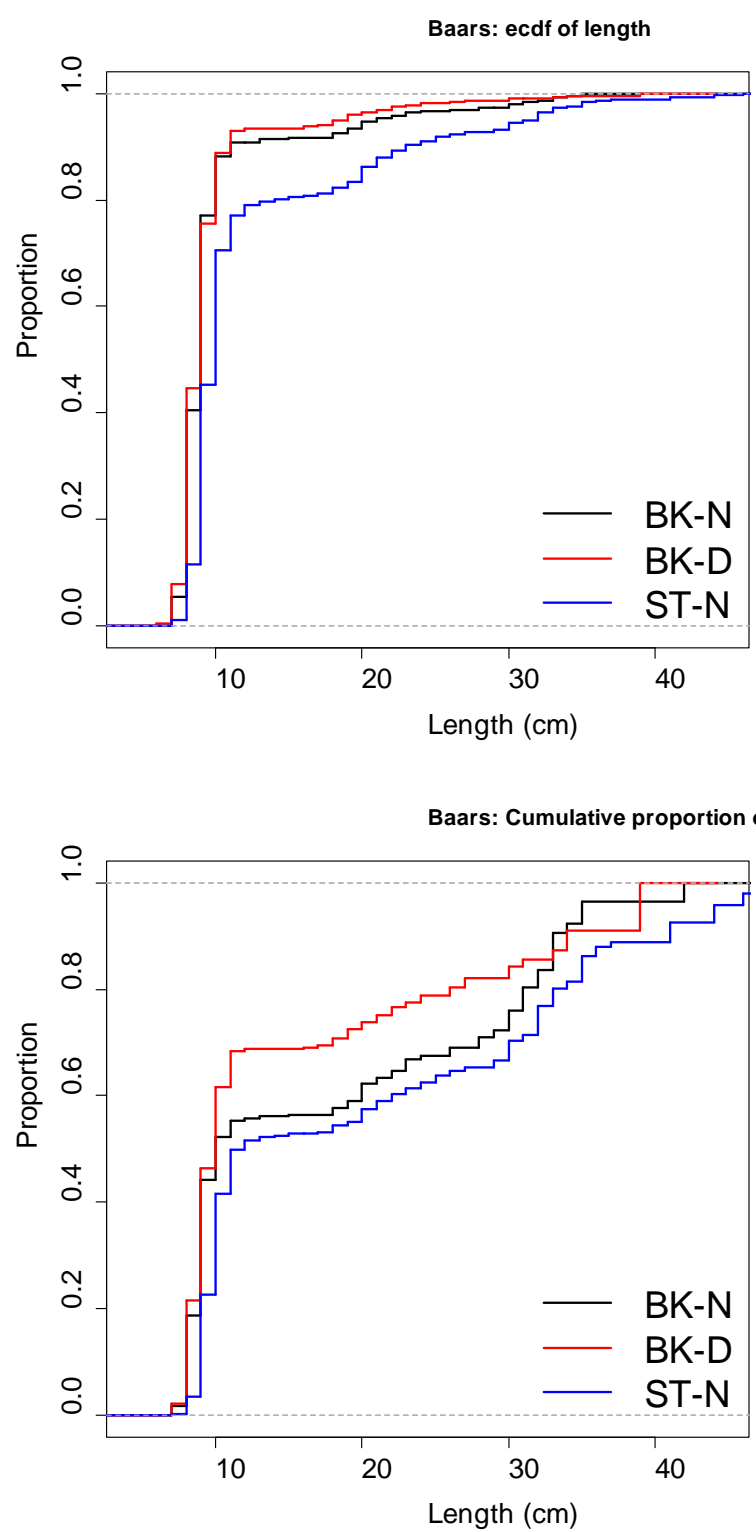

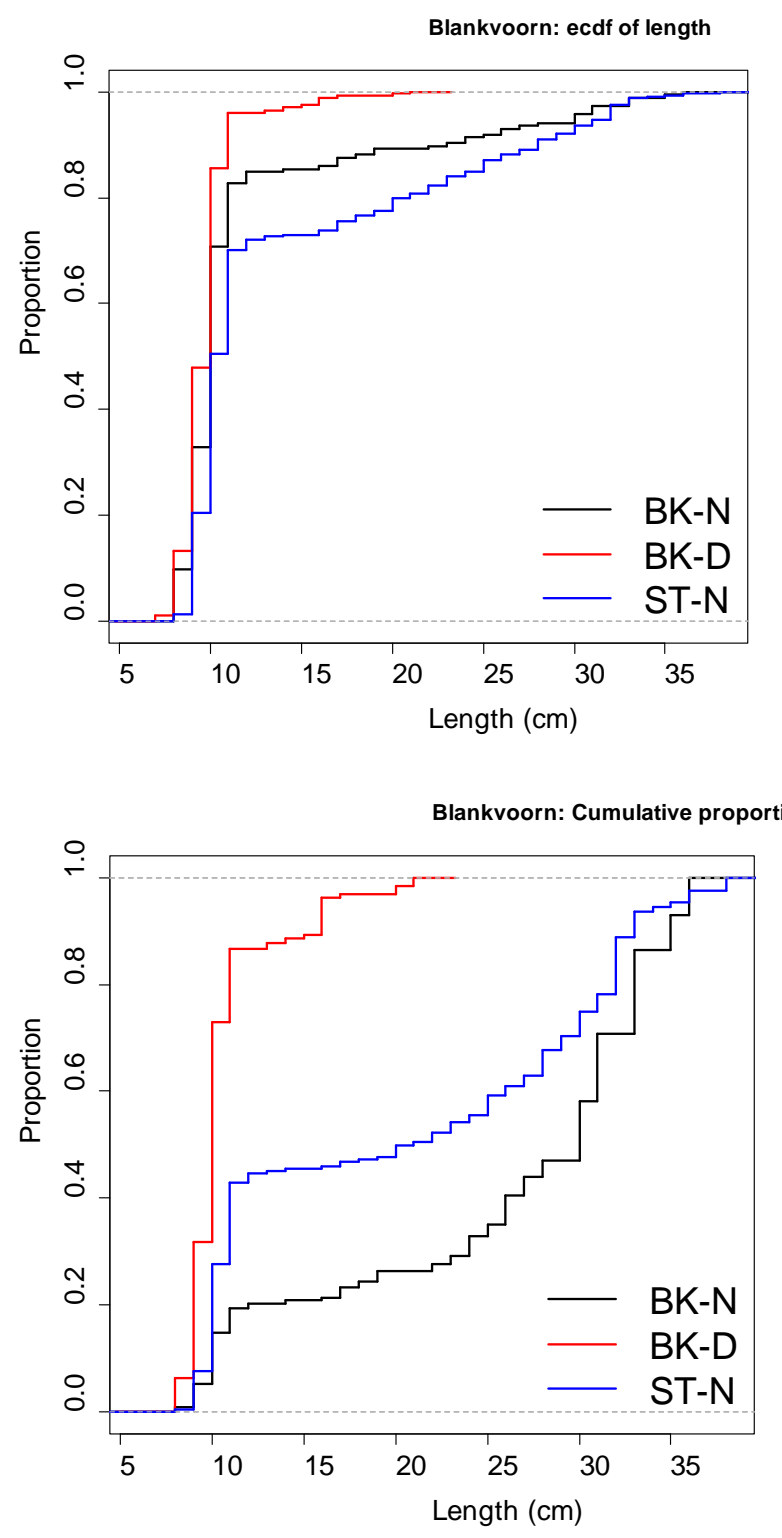

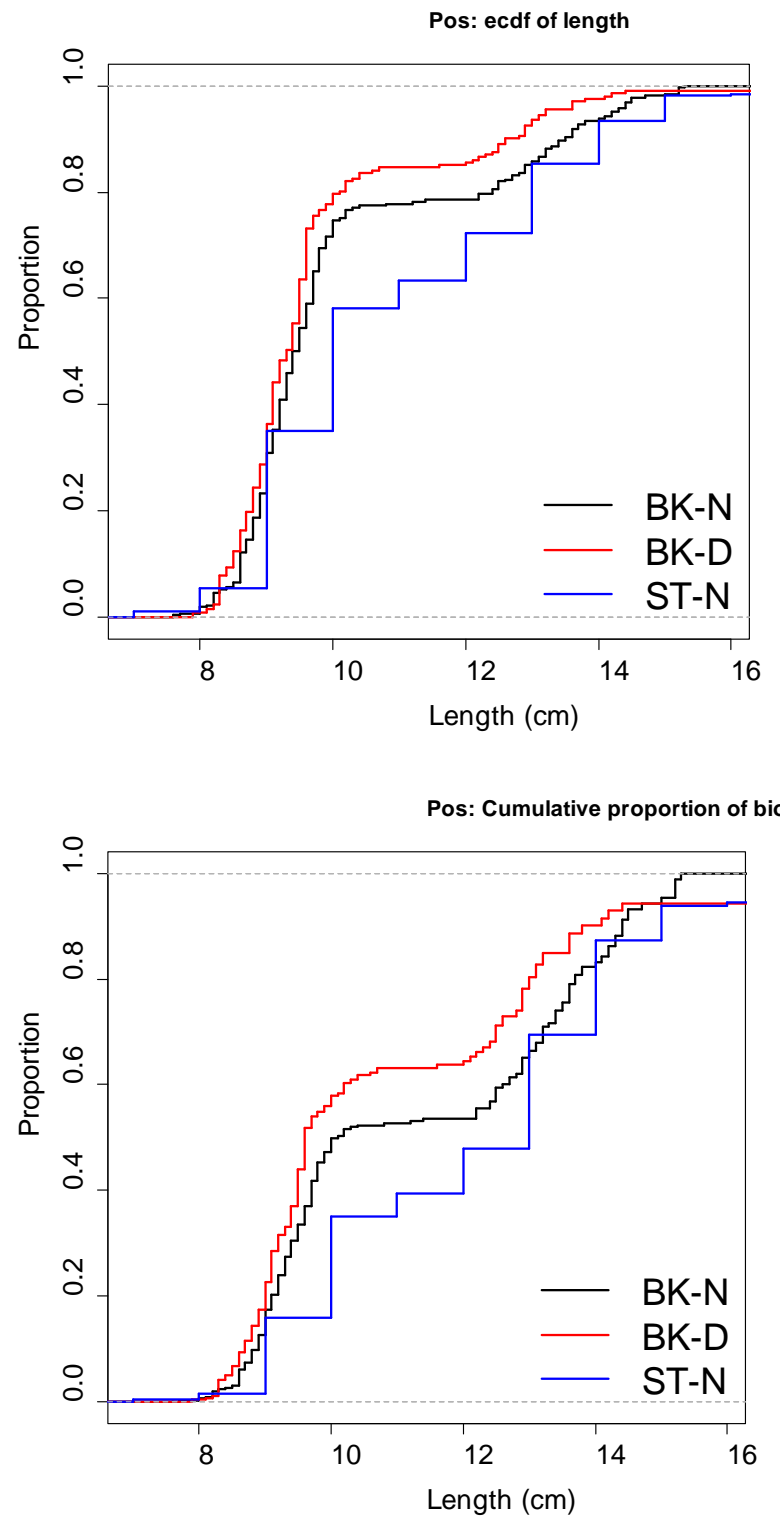

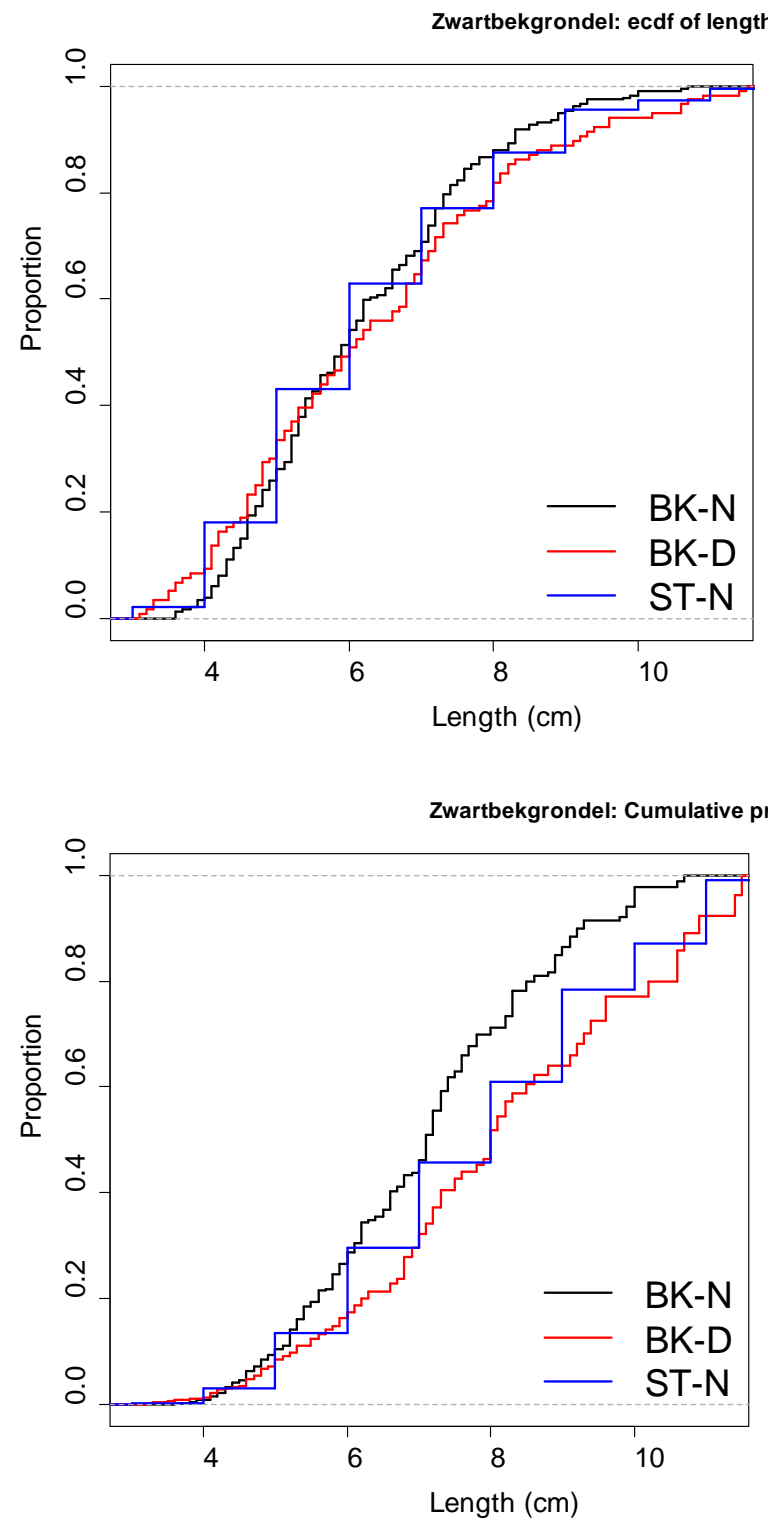

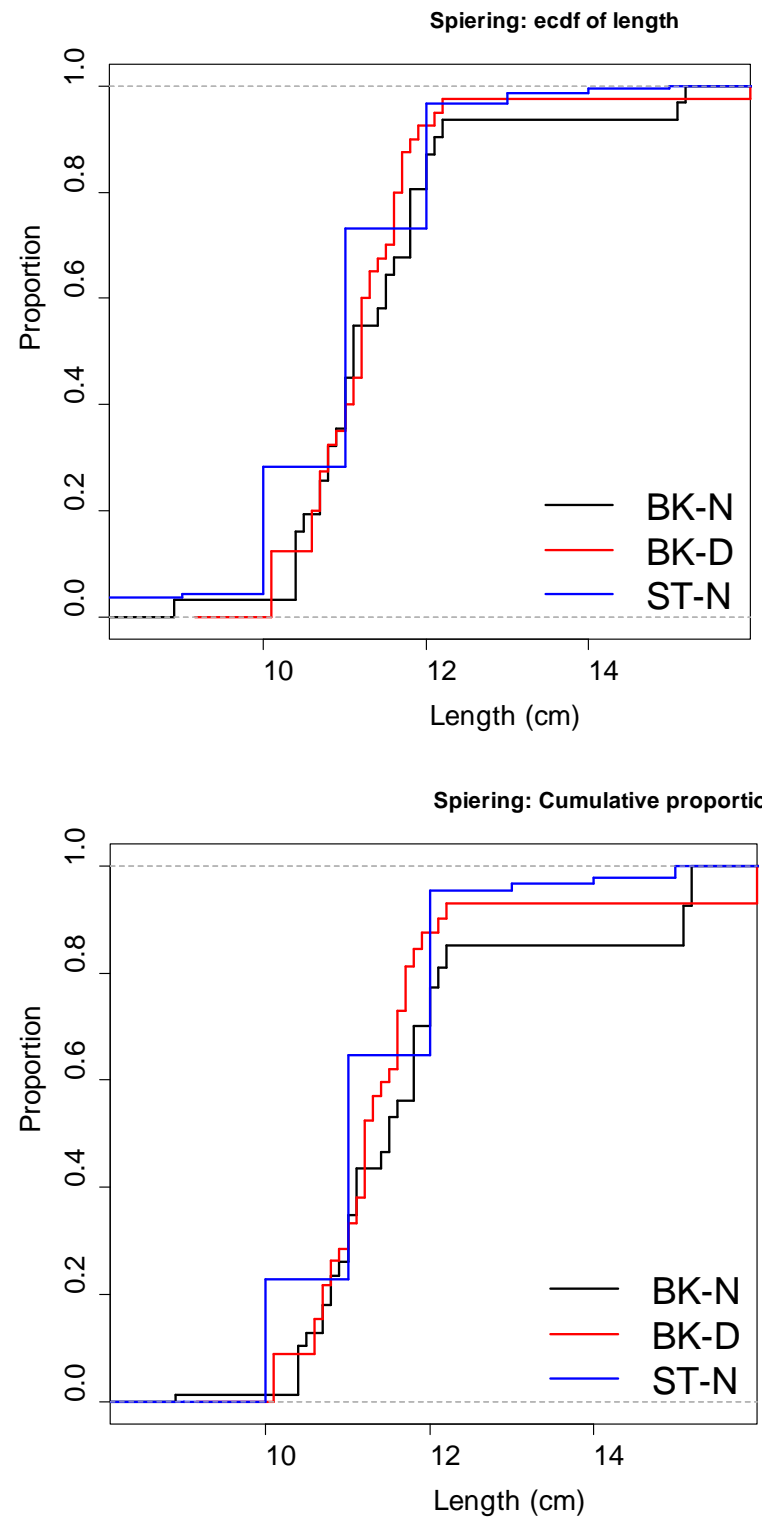

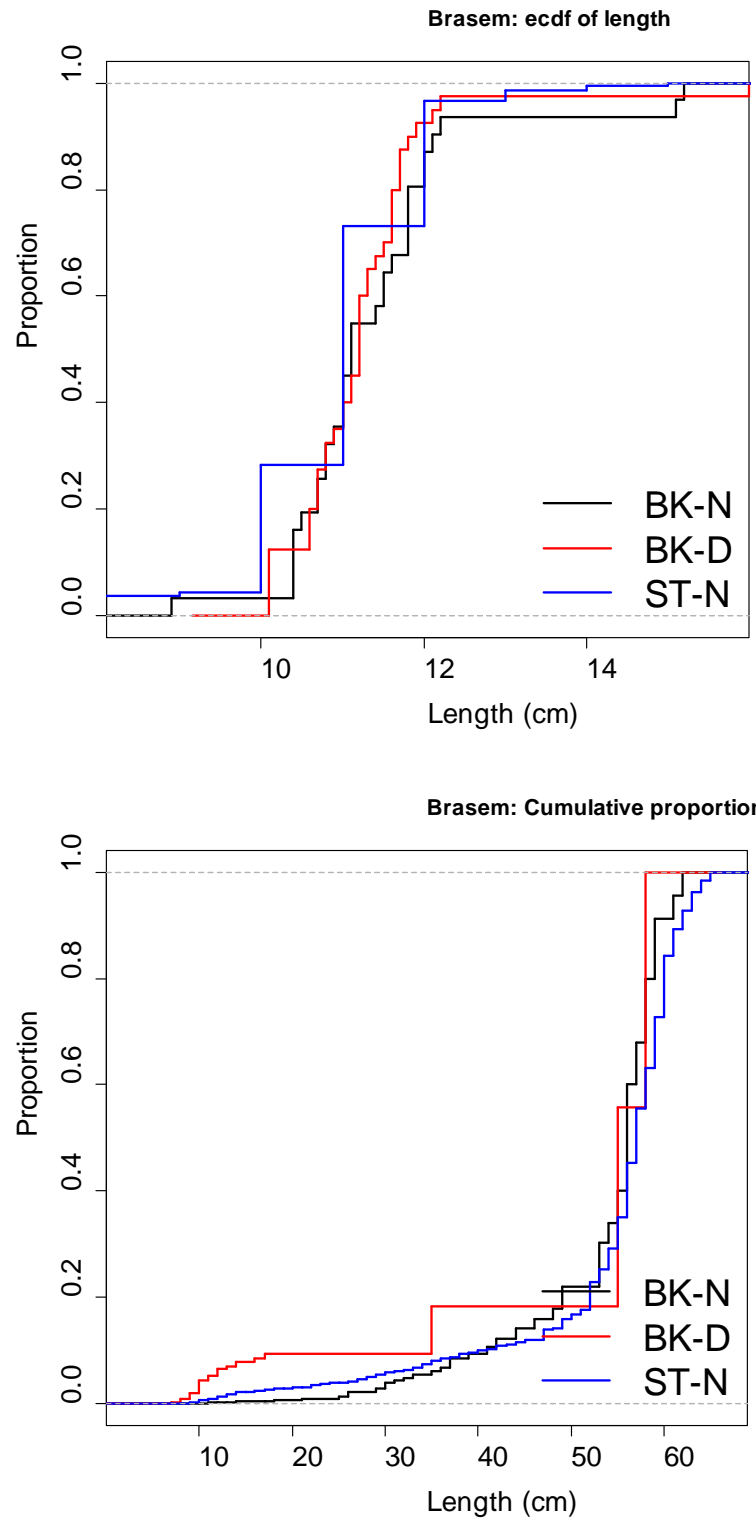

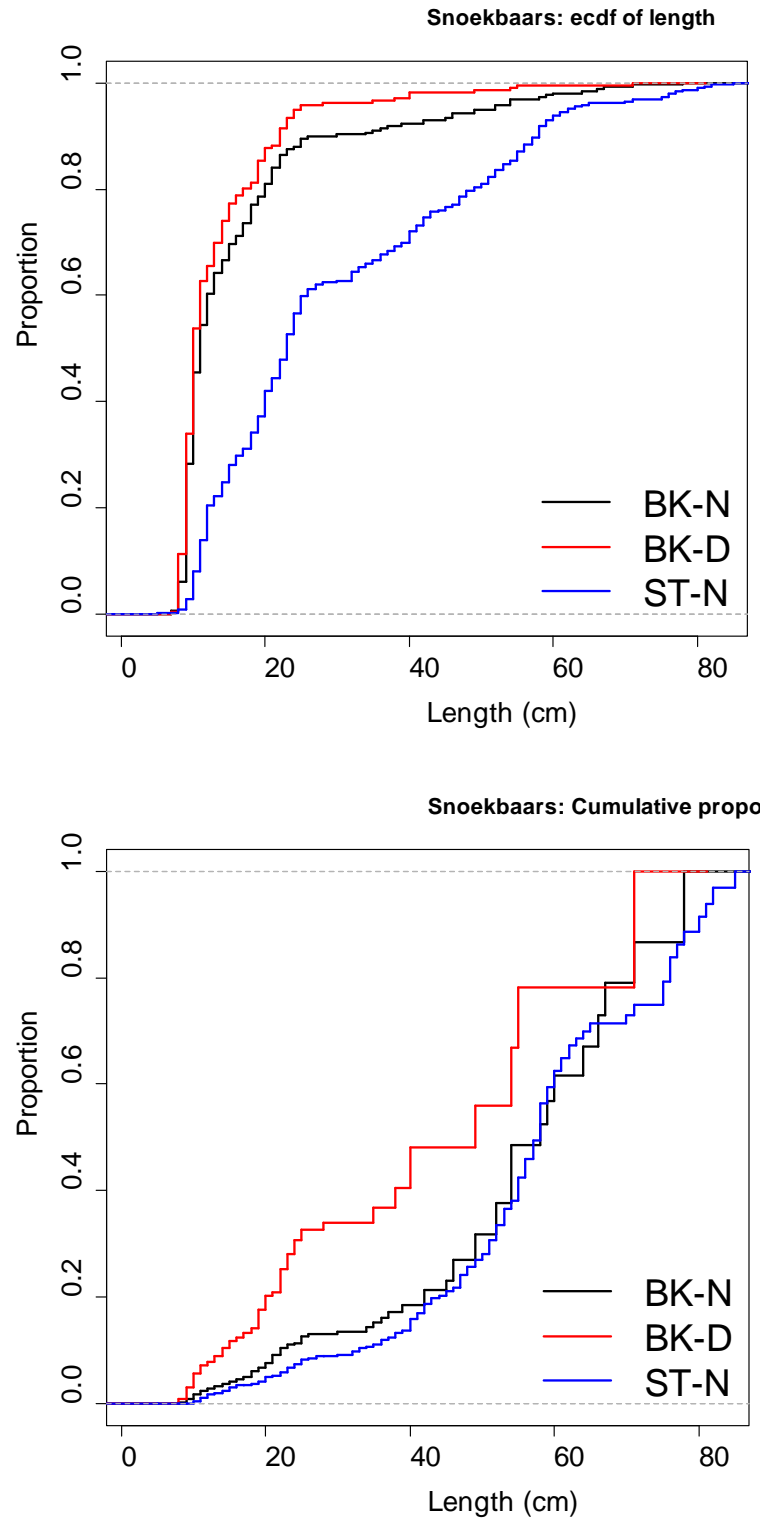


\section{Bijlage 4: CPUE vergelijking per soort}

Brasem: drie nul-vangsten
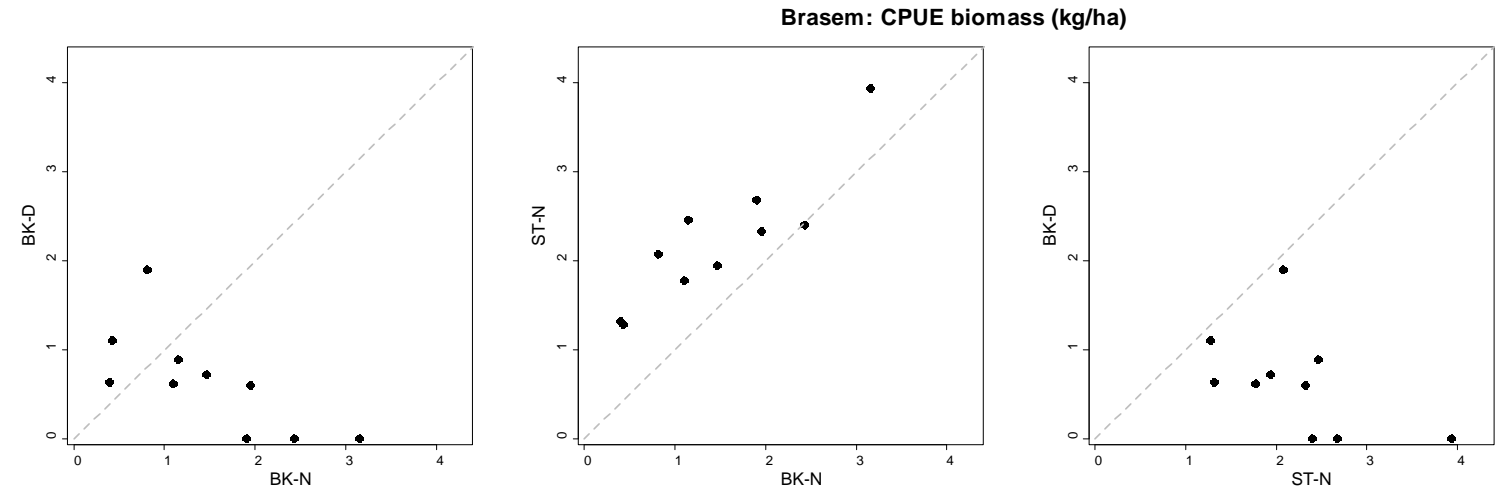

Brasem: CPUE biomass $(\mathrm{kg} / \mathrm{h}$

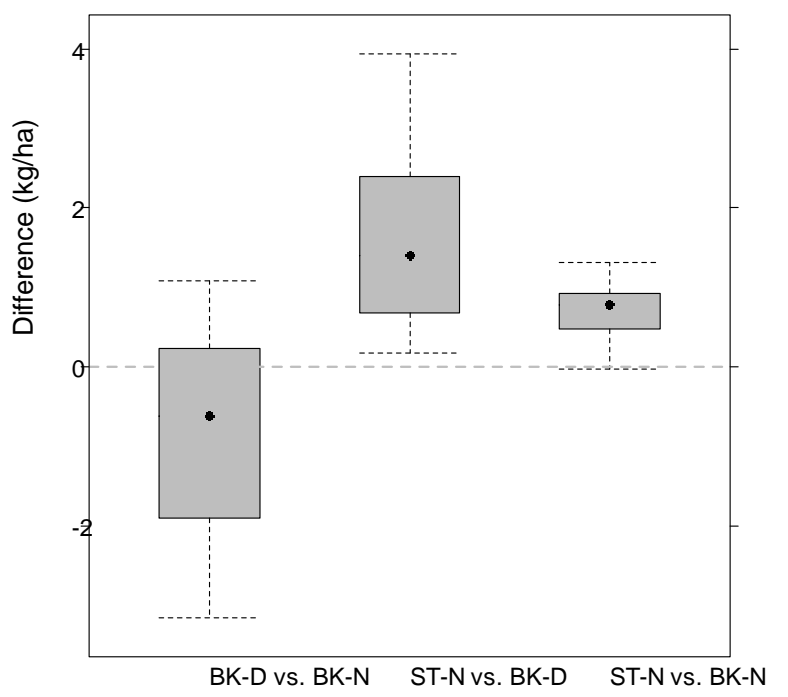

Snoekbaars: twee nul-vangsten
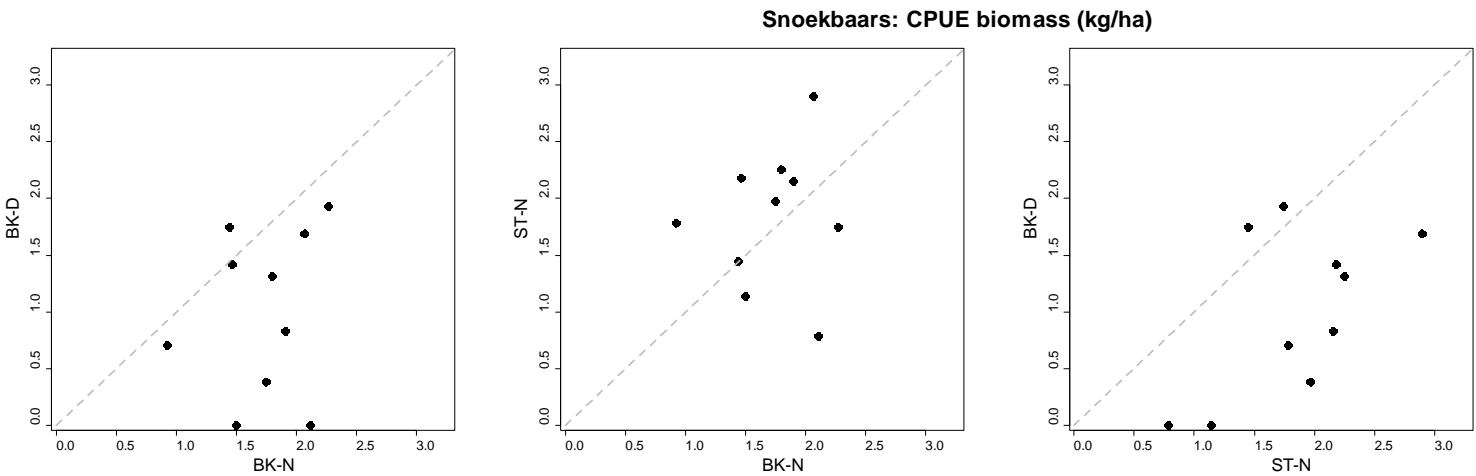
Snoekbaars: CPUE biomass (I

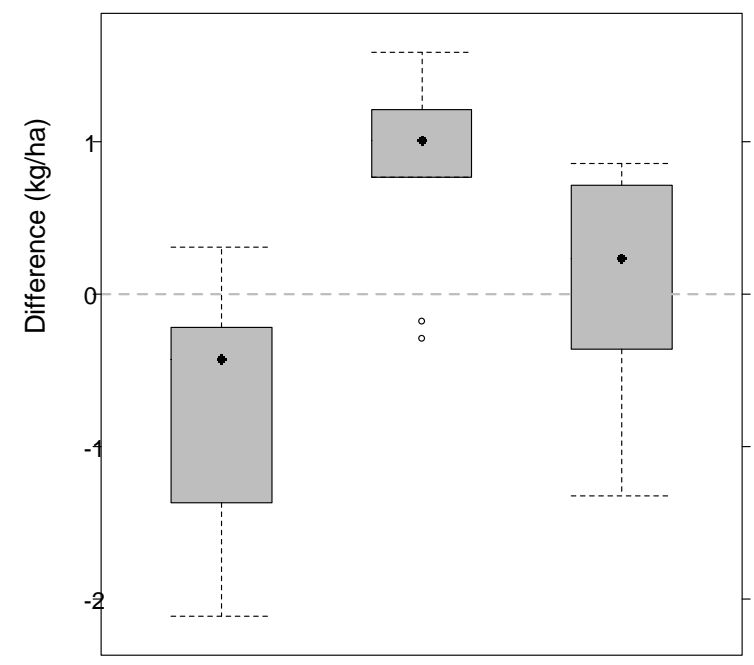

BK-D vs. BK-N ST-N vs. BK-D ST-N vs. BK-N

\section{Baars:}
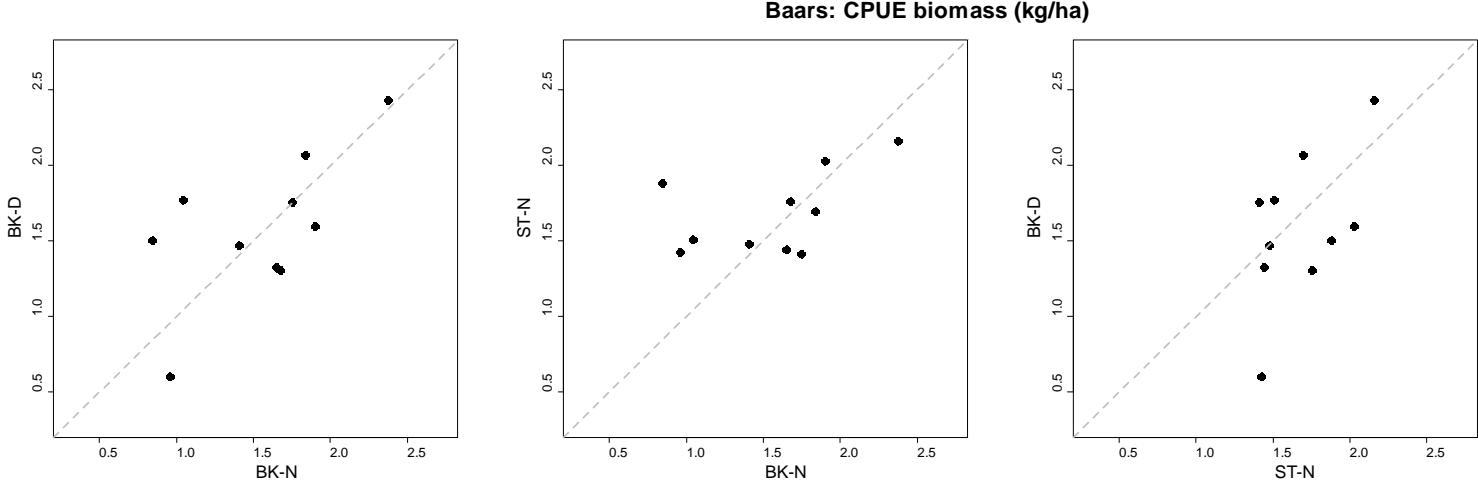

Baars: CPUE biomass (kg/ha)

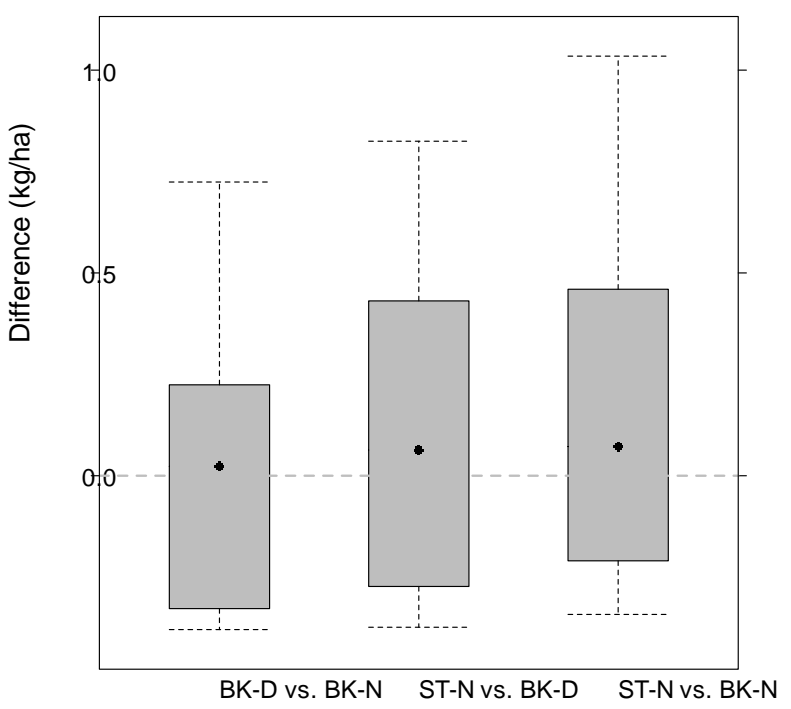

Blankvoorn: drie nul-vangsten 

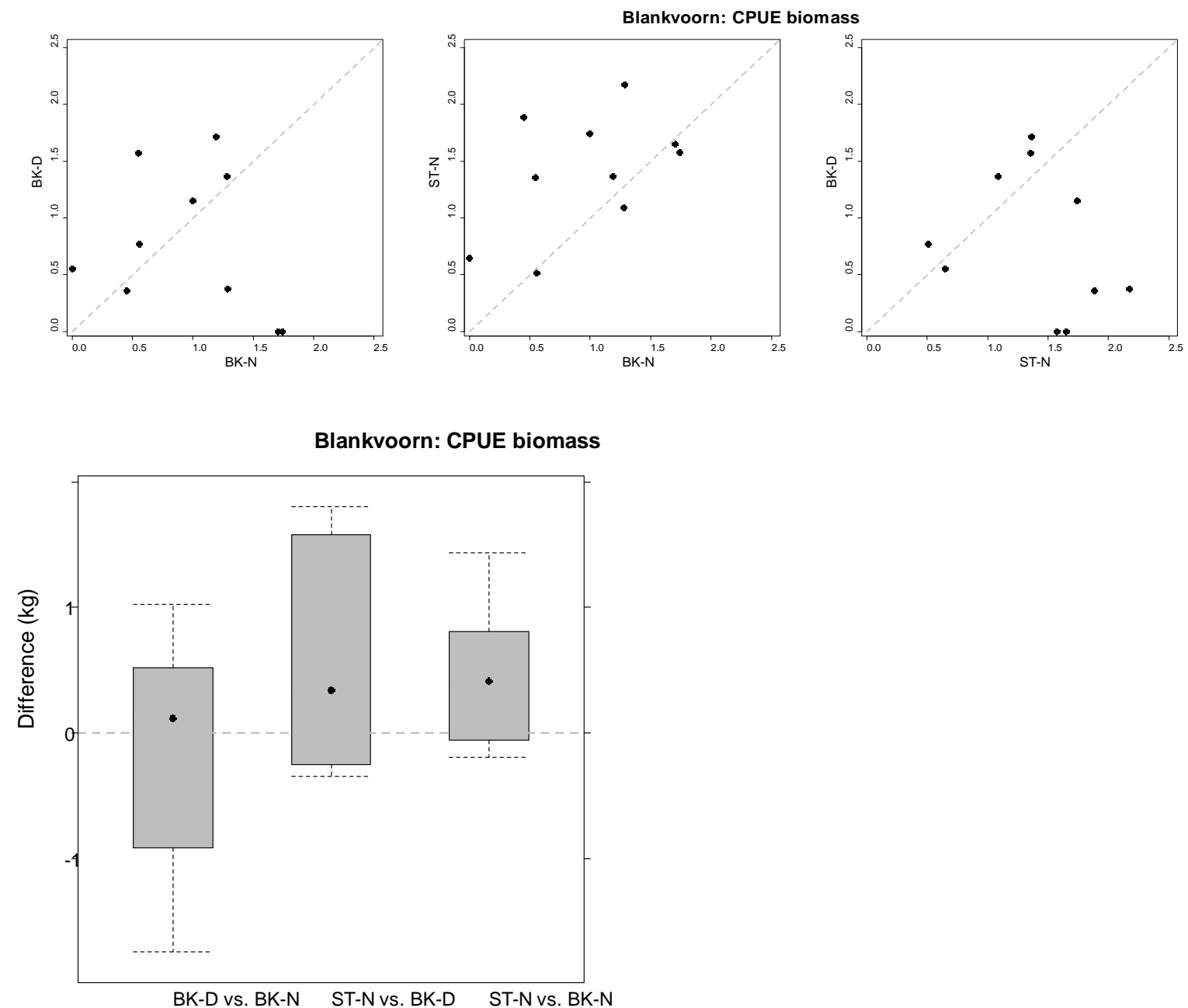

Pos: vier nul-vangsten
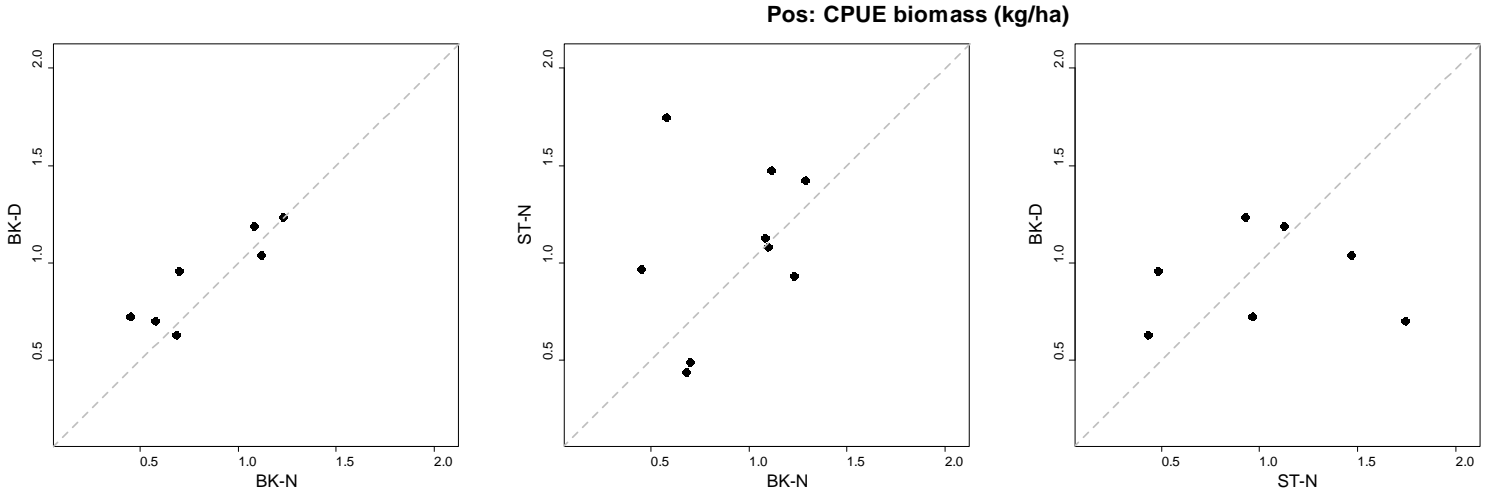
Pos: CPUE biomass (kg/ha)

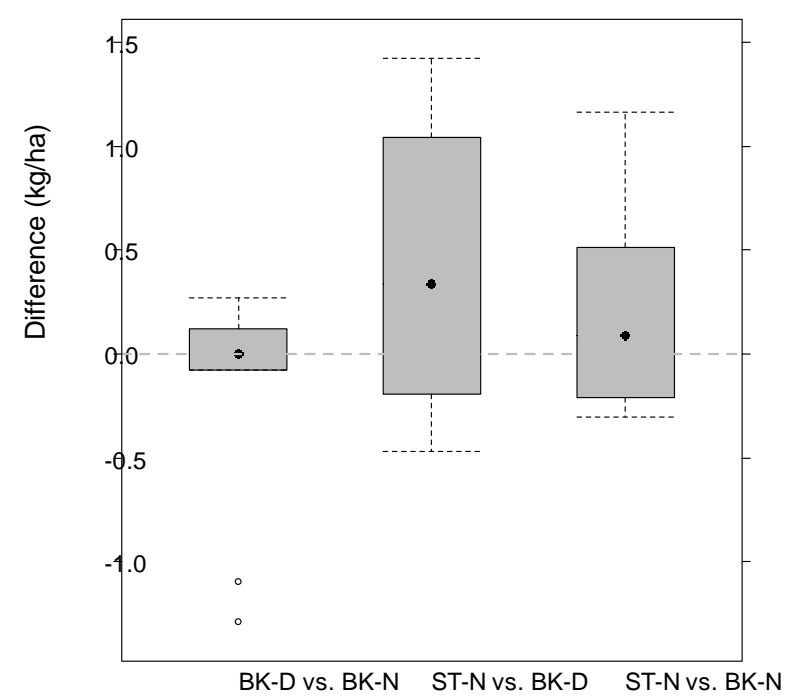

Spiering: zeven nul-vangsten
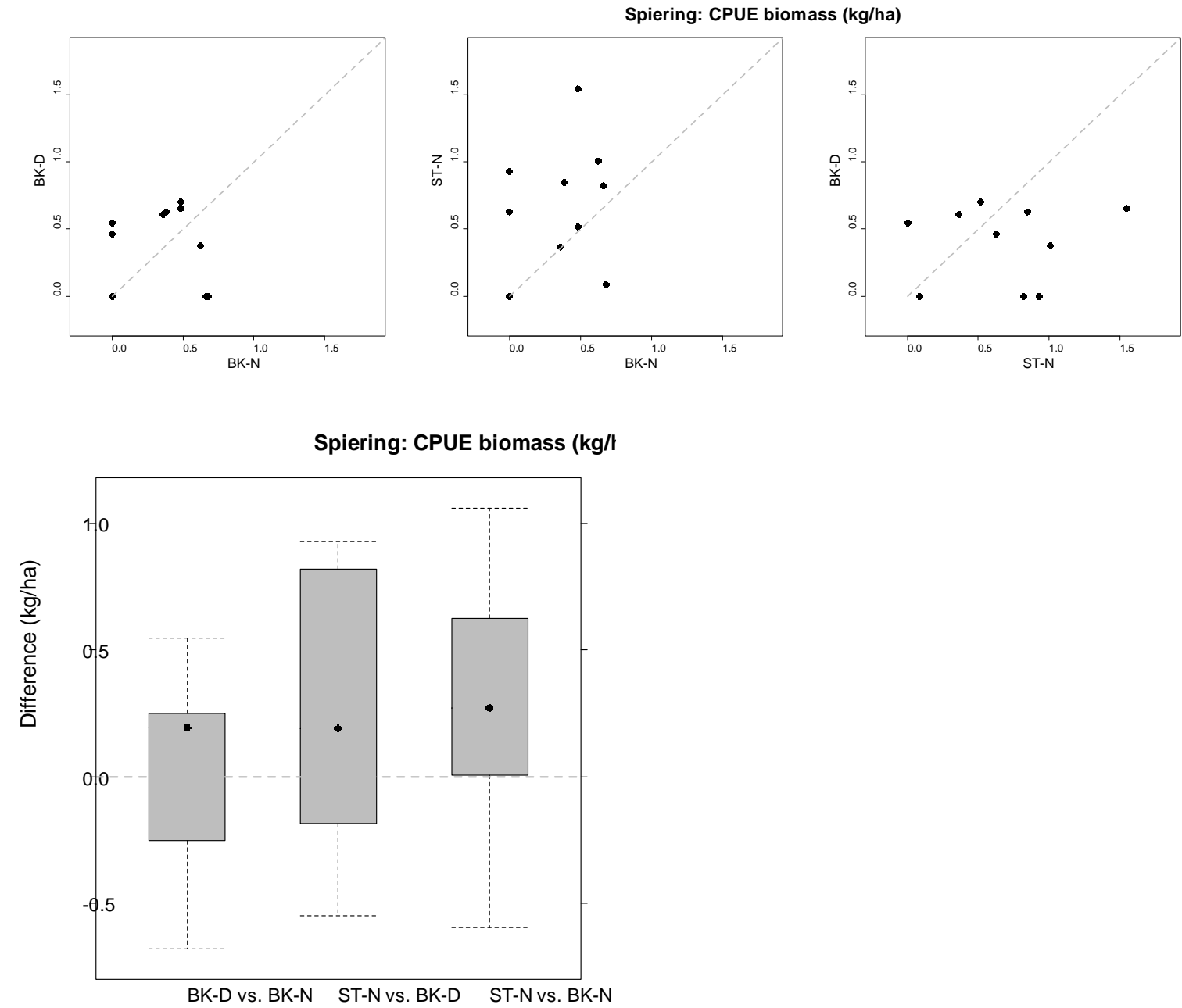

Zwartbekgrondel: vijf nul-vangsten 

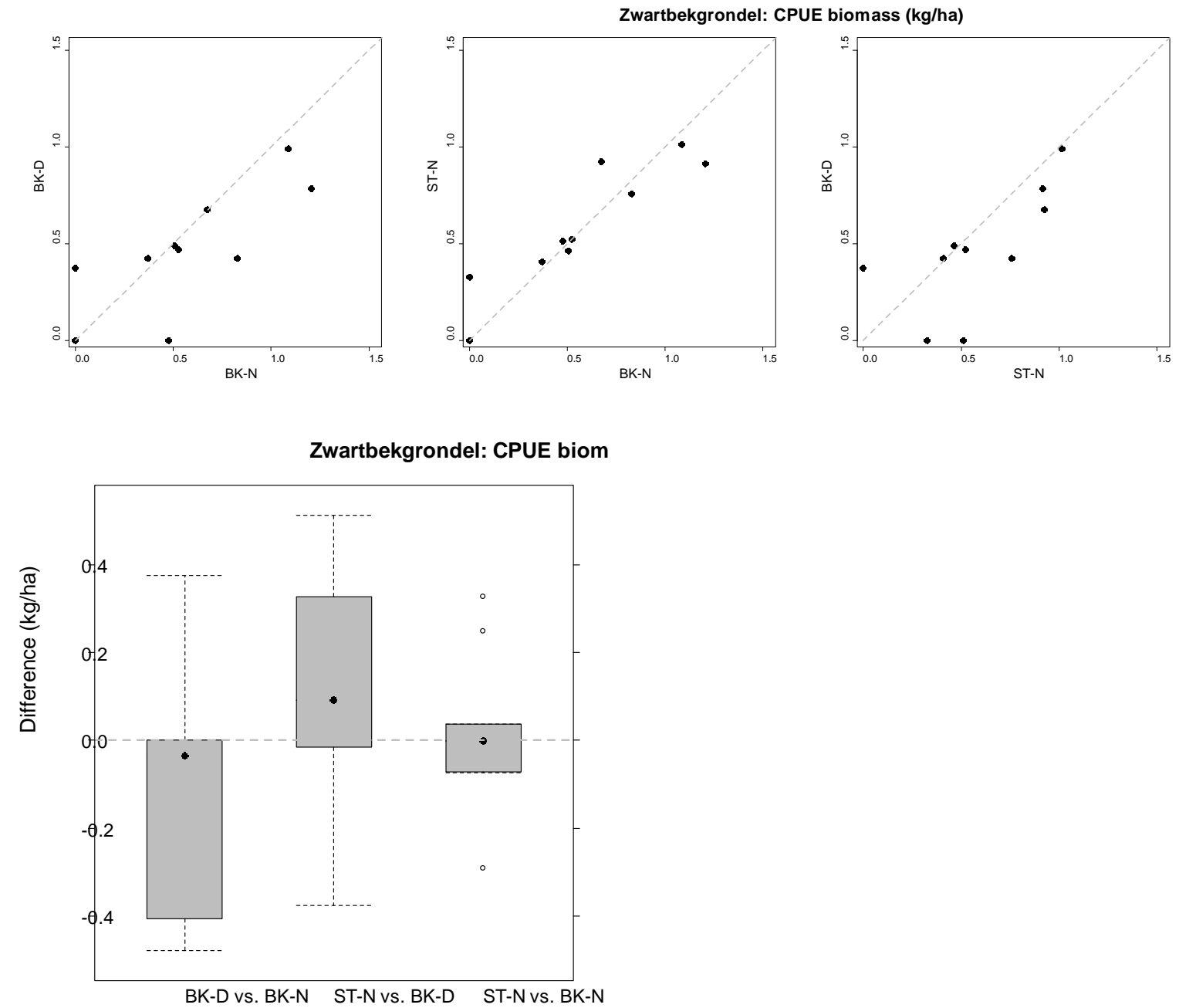
Wageningen Marine Research

T: $+31(0) 317480900$

E: marine-research@wur.nl

www.wur.nl/marine-research

Visitors address

- Ankerpark 271781 AG Den Helder

- Korringaweg 7, 4401 NT Yerseke

- Haringkade 1, 1976 CP IJ muiden
Wageningen Marine Research is the Netherlands research institute established to provide the scientific support that is essential for developing policies and innovation in respect of the marine environment, fishery activities, aquaculture and the maritime sector.

Wageningen University \& Research is specialised in the domain of healthy food and living environment.

\section{The Wageningen Marine Research vision:}

'To explore the potential of marine nature to improve the quality of life.'

The Wageningen Marine Research mission

- To conduct research with the aim of acquiring knowledge and offering advice on the sustainable management and use of marine and coastal areas.

- Wageningen Marine Research is an independent, leading scientific research institute.

Wageningen Marine Research is part of the international knowledge organisation Wageningen UR (University \& Research centre). Within Wageningen UR, nine specialised research institutes of Stichting Wageningen Research (a Foundation) have joined forces with Wageningen University to help answer the most important questions in the domain of healthy food and living environment. 